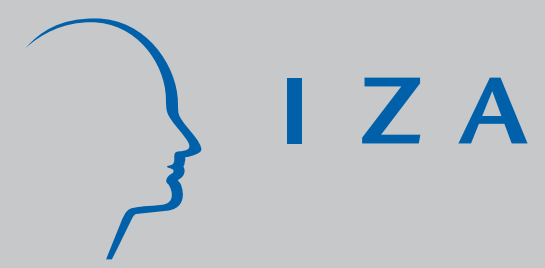

IZA DP No. 7161

Quasi-Experimental Impact Estimates of Immigrant Labor Supply Shocks: The Role of Treatment and Comparison Group Matching and Relative Skill Composition Abdurrahman Aydemir Murat G. Kırdar

January 2013 


\title{
Quasi-Experimental Impact Estimates of Immigrant Labor Supply Shocks: The Role of Treatment and Comparison Group Matching and Relative Skill Composition
}

\author{
Abdurrahman Aydemir \\ Sabancı University \\ and IZA \\ Murat G. Kırdar \\ Middle East Technical University \\ and IZA \\ Discussion Paper No. 7161 \\ January 2013 \\ IZA \\ P.O. Box 7240 \\ 53072 Bonn \\ Germany \\ Phone: +49-228-3894-0 \\ Fax: +49-228-3894-180 \\ E-mail: iza@iza.org
}

Any opinions expressed here are those of the author(s) and not those of IZA. Research published in this series may include views on policy, but the institute itself takes no institutional policy positions. The IZA research network is committed to the IZA Guiding Principles of Research Integrity.

The Institute for the Study of Labor (IZA) in Bonn is a local and virtual international research center and a place of communication between science, politics and business. IZA is an independent nonprofit organization supported by Deutsche Post Foundation. The center is associated with the University of Bonn and offers a stimulating research environment through its international network, workshops and conferences, data service, project support, research visits and doctoral program. IZA engages in (i) original and internationally competitive research in all fields of labor economics, (ii) development of policy concepts, and (iii) dissemination of research results and concepts to the interested public.

IZA Discussion Papers often represent preliminary work and are circulated to encourage discussion. Citation of such a paper should account for its provisional character. A revised version may be available directly from the author. 


\section{ABSTRACT \\ Quasi-Experimental Impact Estimates of Immigrant Labor Supply Shocks: The Role of Treatment and Comparison Group Matching and Relative Skill Composition}

This paper examines the employment effects of a large burst of immigration - the politicallydriven exodus of ethnic Turks from Bulgaria into Turkey in 1989. In some locations, the rise in the labor force due to this inflow of repatriates was 5 to 10 percent. A key feature of our context is the strong involvement of the Turkish state in the settlement of earlier waves of repatriates, which provides us a strong source of exogenous variation in the 1989 immigrant shock across locations and brings our study closer to an ideal natural experiment. Using a reservoir of 342 cities and towns in Turkey with variable treatment intensity, this analysis places much attention on constructing a matched sample that is well balanced in terms of covariate distributions of the treatment and comparison groups - using propensity score matching. We find a positive effect of repatriates on the unemployment of non-repatriates. In fact, a 1 percent increase in the labor force due to repatriates increases the unemployment rate of natives by 0.4 percentage points. When the analysis is done according to skill groups, we find that the impact is the strongest on the young and on non-repatriates with similar educational attainment.

JEL Classification: J21, J61

Keywords: labor force and employment, immigrant workers, quasi experiments

Corresponding author:

Murat G. Kırdar

Department of Economics

Middle East Technical University

06531 Ankara

Turkey

E-mail: kirdar@metu.edu.tr

\footnotetext{
* We are grateful to George Borjas, David Card, Gordon Hanson, Steffen Reinhold, Erol Taymaz and Insan Tunalı for valuable comments and suggestions. We also would like to thank seminar participants at the Institute for Research on Labor and Employment at University of California-Berkeley, Koç University, Middle East Technical University, and TOBB-ETU University, as well as the participants at Econometric Society Asian Meeting, Econometric Society European Meeting, Economic Research Forum Conference, and Norface Migration Network Conference for their valuable comments. Funding from the Migration Research Program at Koç University is gratefully acknowledged. All errors are our own.
} 


\section{Introduction}

There exists a large literature that explores the labor market impacts of immigration on receiving countries. This paper seeks to identify the impacts of immigration on employment prospects of the native born, using a large-scale exodus of ethnic Turks from Bulgaria into Turkey within a span of three months in 1989, which resulted from political events. The context is similar to other natural experiment studies where an exodus of immigrants due to political factors in sending countries result in large supply shocks in the labor markets of receiving countries (Card 1990, Hunt 1992, Carrington and Delima 1996, Friedberg 2001, Mansour 2010, Glitz 2011). Similar to so called "area studies" (see, e.g., Altonji and Card 1991, LaLonde and Topel 1991, Pischke and Velling 1997, Boustan et al. 2010), the natural experiments approach defines labor markets by geography and exploits the geographic variation in immigrant supply shock for identification. Studies in this literature mostly report small or no impact of immigration on native outcomes. An alternative approach exploits variation in the size of immigrant supply shocks across skill groups at the national level and reports much larger impacts (Borjas, Freeman, Katz 1992, 1996, 1997; Borjas 2003; Aydemir and Borjas 2007).

An important advantage of studies that exploit natural experiments is that since these

flows are initiated by political factors, the flows are largely independent of general economic conditions in both the sending and the receiving countries. The natural experiment in our study; the emigration of ethnic Turks from Bulgaria driven by the assimilation campaign in Bulgaria; is a typical case of political migration (Vasileva, 1992). This emigration was not driven by economic decisions of repatriates, and the resulting supply shock was unpredicted in the Turkish labor market. The Turkish government opened its borders partly in response to an international outcry for the worsening situation of ethnic Turks in Bulgaria (Amnesty International, 1986), and for internal political reasons. Therefore, the actions of neither the Bulgarian nor the Turkish government were associated with the past or future employment outcomes in Turkey.

A major threat to identification for area studies, including the type of natural experiments above, is that immigrants may choose to settle in locations in the receiving country that have 
better labor market prospects. This means that shocks across local labor markets are not random, which results in a downward bias in the estimated impacts. For this reason, many studies that follow the area approach use the immigrant stock in a previous time period as an instrument for the location choices of new immigrants (e.g., Altonji and Card, 1991; Schoeni, 1997; Card, 2001). We take a similar approach using the facts that there were several waves of repatriates from Bulgaria prior to the 1989 flow and that many of the 1989 repatriates chose to settle in regions where previous waves of repatriates from Bulgaria resided.

Even when new immigrants choose their locations according to their compatriots' location of residence, if the distribution of the location of residence of their compatriots is correlated with the economic conditions across these locations, questions would arise about the validity of the instrument. However, unlike the previous literature using this type of an instrument, in the Turkish context, historically, the state organized the migration of ethnic Turks from Europe by choosing the locations of settlement for these migrants according to the similarity of climate and land characteristics to the origin areas, and by constructing housing for them in these regions. We provide both historical and current substantial evidence supporting that the resulting initial settlement regions of earlier compatriots were independent of economic conditions and these earlier compatriots did not relocate significantly due to economic reasons before the arrival of 1989 repatriates.

Another critical issue for identification that has received much less attention in naturalexperiment studies that exploit geographical variation in the immigrant supply shock is the construction of comparison groups that are sufficiently well-balanced with the treatment group in terms of pre-treatment covariate distributions. The importance of the balance in pre-treatment characteristics in difference-in-difference estimators has been discussed in the literature (Meyer, 1995; Angrist and Krueger, 1999; Abadie, 2005). For difference-indifference estimators that follow an instrumental variable strategy, this issue is also highly relevant because a failure of the conditional independence assumption for the instrument in a sample with poor covariate balance between the treatment and comparison groups may lead to serious omitted variable bias. Therefore, we pay much attention to finding appropriate comparison cities in this study. In particular, we match the cities and towns in our sample based on an estimated propensity score of receiving repatriates in order to construct a sample 
with more overlap in the distributions of several covariates of the treatment and comparison groups. This method allows us to check the sensitivity of our findings to any potential omitted variables across locations. (When we compare the cities and towns with different treatment intensity in this study, we call the cities and towns with low treatment the comparison group.) In addition, we analyze the effect of immigration on treatment groups defined by gender, education and age, separately. ${ }^{1}$

Our data allow us to examine the employment impact of these repatriates at a finer level compared to the previous literature: across 342 cities and towns in Turkey with a population above 10,000 in 1985. The labor market conditions of these 342 locations, both before and after the labor supply shock, are observed in our data. Out of these 342 locations, 99 received varying levels of immigrant shocks. While the size of the shock was only about 0.7 percent of the Turkish labor force, the geographical concentration of repatriates led to much larger increases in certain locations; in fact, the rise in the labor force was above 10 percent in 2 locations. Among the top twenty destinations where repatriates settled, the average increase in the labor force due to repatriates was 4.0 percent. The size of the shock is among the largest shocks reported in literature exploiting natural experiments.

Another important feature of our natural experiment is that the shock is realized over a very short period of time of only three months. However, this is not an oft-seen property of the studies utilizing natural experiments in this field - the exceptions are Card (1990) and Hunt (1992) — as immigration is typically realized over longer periods of time. When immigration takes place over longer periods of time, the shock could be partly expected, leading to adjustments in the market, whereas the labor supply shock was not expected in our case. In addition, the fact that there were no other major shocks to the economy when the 1989 immigrant flow was realized aids identification. Finally, the evidence we present for the lack of response in terms of native migration yields more justification to our methodology.

Our findings reveal that when the analysis is carried over all 342 cities and towns with a population above 10,000 in Turkey in 1985, there is a small positive impact of repatriates

\footnotetext{
${ }^{1}$ Dustmann et al. (2005) examine the impact of immigration on education groups separately; however, this study is not based on a natural experiment. An example to a natural-experiment study, on a different topic, that examines the differential impact on various skill groups is Card and Krueger (1994).
} 
on the unemployment of non-repatriates, which is similar to the findings of the previous literature that utilizes natural experiments. However, as we improve the overlap in covariate distributions of the treatment and comparison groups via matching through an estimated propensity score of receiving repatriates, the magnitude of the effect of repatriates increases substantially. A 1 percent increase in the labor supply due to repatriates increases the unemployment rate of non-repatriates by about 0.4 percentage points. In other words, for every 10 repatriates that enter the labor force, 4 non-repatriates lose their job while 5 new jobs are created. We also examine whether the repatriates have any effect on the labor force participation of non-repatriates; however, we do not find any evidence for that.

The effect of immigrants on native employment that we estimate in this paper is larger than those in most other studies. In our context, immigrants are close substitutes to natives because they have the same ethnicity, speak the same language, and lived in a neighboring country. This high level of substitutability restricts the mitigating influence of immigrants on the native labor market through complementarity in production. In fact, we find that the impact of repatriates is the strongest on non-repatriates with similar educational attainment and on younger non-repatriates.

In terms of methodology, we find that when the covariate distributions of the treatment and comparison groups are not sufficiently well-balanced, the bias resulting from unmeasured factors in which the treatment and control groups are not comparable is significant. This bias persists in the 2SLS estimation because the conditional independence assumption required for a valid instrument is less likely to hold when there are several unmeasured factorsin which the treatment and control groups are not comparable that are not controlled. However, as we improve the covariate balance between the treatment and comparison groups through matching, this bias is substantially reduced. Therefore, this study also illustrates that combining the construction of a matched sample with instrumental variables estimation could be very valuable in evaluating the labor market effects of immigrants.

The next section reviews the context in which the repatriates arrived, the factors that determined the regions of settlement, and the resulting supply shocks. Section 3 discusses the conceptual framework of our analysis, and Section 4 describes the data along with the geographic distribution of repatriates. The empirical model and the estimation strategy are 
discussed in Section 5, and the results in Section 6. Section 7 concludes.

\section{Background Information}

\subsection{Repatriate Flows to Turkey}

The Balkan region housed a large population of ethnic Turks under the Ottoman rule, whose numbers started declining significantly following the wars in the region at the end of the 18th century. This continued after the 1st World War and the foundation of the Republic of Turkey. In fact, large population exchanges between Turkey and Balkan states took place during this period. Over the 1934-1960 period, 47 percent of the migrants arriving in Turkey

originated from Bulgaria alone and 80 percent from the Balkan region. Between 1950 and 1989, the flow of migrants from the Balkan region was almost entirely from Bulgaria.

The first massive migration from the Balkans in the 19th century occurred following the Balkan Wars in 1912-1913. An estimated number of 440,000 immigrants were forced to move by Bulgarian forces to Anatolia during this period (Konukman, 1990). Following the establishment of the Republic of Turkey in 1923, there were four massive flows from Bulgaria either as a result of treaties or as forced migration. The first started in 1925 following the agreement signed by Bulgaria and Turkey that resulted in the voluntary resettlement of 219,000 migrants in Turkey. This was followed by the 1950-51 flow after Bulgaria became a communist state and forced migration of ethnic Turks until Turkey closed borders in 1951, which resulted in 154,393 migrants. The sudden stop left many families fragmented. In order to unite separated families, the "Close Relative Migration Agreement" was signed between the two countries in 1968, leading to the arrival of 116,521 migrants (Doganay, 1996). As the communist state strictly controlled emigration starting with early 1970s, there was almost no migration from Bulgaria for the next two decades until the massive migration of 1989.

The events that led to the forced migration in 1989 started with the Bulgarian government's new assimilation campaign initiated in 1984. The campaign involved a systematic effort to forcibly change Turkish names to Bulgarian ones, a ban on the speaking of Turkish in official quarters, and the denial of the existence of ethnic Turks. Those who resisted were 
sent to various labor camps or imprisoned (Amnesty International, 1986). The campaign peaked with the transportation of ethnic Turks to the Turkish border in order to force them to emigrate, which led to a massive build-up. As a result of both domestic and international public outcry, Turkey opened its borders. Over the course of the period between May 26 and August 21, 1989, a large emigrant wave was realized in Turkey. The rights of non-Bulgarian citizens were gradually restored in the years following the fall of the communist regime in Bulgaria in November 1989, leading to the return migration of some Turks who were expelled from the country.

In the 1990 Turkish Census, conducted in October 1990, there were 460,560 individuals of all ages counted as born in Bulgaria. Among these, 169,260 are reported to have arrived over the last five years, which refers to the 1989 wave. In the 1985 Census, on the other hand, 291,960 individuals were counted as born in Bulgaria, and about 1,540 of them arrived over the five years prior to Census. As there was practically no immigration from Bulgaria after the late-1960s wave of immigrants, the 1989 influx was the first massive wave in the following two decades and led to a 56 percent increase in the Bulgarian-born population in Turkey.

While the number of individuals born in Bulgaria counted in the 1990 Census stands at around 170,000 individuals, the estimate for the number of forced emigrants ranges from 226,000 to more than 300,000 (DPT 1990). The difference between the number of immigrants that arrived and those enumerated by the Census about a year later suggests that there was substantial return migration among the 1989 cohort of immigrants. These migrants were forced to leave all their properties back in Bulgaria such as their land, equipments, houses, personal belongings, savings in bank accounts and all social rights. They had a chance to reclaim them with the regime change in their homeland. The regime change also allowed the reunification of divided families across the border, caused by the forced migration, which was estimated to be around 80,000 (DPT, 1990). It is important to note that like the forced emigration to Turkey, the return migration of those who arrived in 1989 was also largely a result of the political developments in Bulgaria; that is, it was unlikely to be a result of economic conditions in either country.

Under both the Ottoman rule and the Republic, the state organized these moves and 
pursued a policy that placed most of these migrants around the northwestern and western provinces of Turkey where the Marmara region was the focal point. ${ }^{2}$ The choice of these regions was motivated by the similarity of the climate and land characteristics to regions where these migrants used to live, as well as a policy of populating certain regions. The placement policy worked mainly through providing state funded housing and land to the migrants. While the fraction of migrants settled by the state varied over time as shown in Figure 1, it was especially high for those arriving from Bulgaria over 1934-1937, among whom 86 percent were settled by the state. This fraction reached 100 percent for the 1950-51 cohort (Geray, 1962).

The construction of housing for migrants was a policy followed since the establishment of the Republic. Housing was built in several cities in Turkey, with a significant proportion in the Marmara region. Figure 2 in the Appendix presents the number of housing units built for all immigrants over the 1934-1960 period. The spike starting in 1951 is due to the housing construction effort following the arrival of the 1950-51 cohort of migrants from Bulgaria, which constituted almost all of the migrant flow to Turkey during those years. Those who arrived as a result of the 1968 agreement, however, were not provided housing as they were mostly relatives of those who arrived in 1950-51, separated by the closing of the borders in 1951. These migrants chose to settle close to their relatives (Geray, 1962 and DPT, 1990). Similar to the previous waves of migration, government sponsored housing construction was also initiated for the 1989 wave for 21,500 families.

\subsection{Relevant Characteristics of the Labor Market in Turkey}

Several studies report that the Turkish labor market is quite dynamic and there is significant flexibility in employment adjustments. Tunalı (2003) reports, based on a sample of establishments covered by Unions Law of the Turkish Ministry of Employment and Social Security, that the amount of annual inflow/outflow as a fraction of total employment was around 30 percent during the 1990s. Given that the workers employed at these establishments have the highest level of employment protection in Turkey, this turnover number is

\footnotetext{
${ }^{2}$ See Figure 4 for a map of Turkey.
} 
striking. Moreover, a significant share of the workers in the Turkish labor market is employed in the informal sector, where we would expect even higher turnover rates. According to the Household Labor Force Survey of the Turkish Statistical Institute, about 30 percent of employment in urban areas was in the informal sector in 2000 (the first year for which this information is available).

Taymaz and Özler (2005) provide an international comparison, albeit for a later time, using the Turkish Household Labor Force Surveys for 2000-2002: they report that compared to most European countries, the flow into unemployment is higher and the unemployment duration is lower in Turkey; in fact, both the values for the flow into unemployment and unemployment duration are similar to those in North America.

Another important feature of the Turkish labor market is that, due to the young population of Turkey, many young people enter the labor market as unemployed each month. Therefore, in a pool of job seekers of which many are young, experienced and hard-working repatriates from Bulgaria would certainly stand out.

\section{Conceptual Framework}

In a general-equilibrium framework, an inflow of immigrants would shift the labor supply to the right. In the short run, this would only lower wages with no effect on unemployment; however, as equilibrating labor and capital flows take place, this effect would also dissipate. However, if the wages are sticky in the downward direction, there would be an increase in unemployment in the short run. Angrist and Kugler (2003) and Glitz (2011), who find a negative impact of immigrants on native unemployment - unlike most other studies in the literature - cite reduced flexibility in the labor market (due to employment protection, union coverage, minimum wages) as the primary underlying cause of their finding.

Given the high inflation environment in Turkey in the late 1980s, we could expect a low level of stickiness in real wages. This would certainly help new job creation after the arrival of repatriates. On the other hand, to the degree that there is no perfect adjustment of wages to the new equilibrium level, there will be unemployment in the short run. In this case, the effect of immigrants on native unemployment depends on the extent that immigrants fill 
the vacant positions at the expense of native workers and replace employed natives. This, in turn, hinges on the characteristics of immigrants and the labor market. Earlier waves of repatriates from the Balkans established a very good reputation for their work ethic in Turkey. Moreover, repatriates were fluent in Turkish and there were no legal barriers in their entry to the labor market. The labor market structure in Turkey - in particular the high level of worker turnover and the high number of inexperienced young workers entering the labor market, as reviewed in the earlier section - would also help the repatriates in securing jobs at the expense of local workers.

In the longer run, we would expect equilibrating factor flows to dissipate the initial impact of repatriates. We observe non-repatriates' employment status 14 months after the arrival of repatriates, which is a long enough period for labor demand to adjust to some degree. A rise in labor demand - which is the main explanation to the observed small effect of immigrants in several studies (Card, 1990; Friedberg, 2001) - would lower the rise in unemployment when wages do not fully adjust.

\section{Data and Descriptive Statistics}

The data used in the analysis are the 1985 and 1990 Turkish Censuses conducted in October of the corresponding years. These files are one in twenty random samples of the population. Censuses include information on age, gender, highest educational attainment, labor force status, and sector of employment. The data do not include information on wages; therefore, we cannot study the impact of the repatriate shock on wages. We restrict our micro-sample to 16 to 65 year olds who are in the labor force.

In 1985, Turkey was divided into 67 provinces that were further divided into several counties. Census data report the location of residence of all individuals. This information identifies the province and county of residence, whether the area of residence is a provincial center, a county center, a town that is not a county center, or a rural area. Between 1985 and 1990, new counties and county centers were formed. The analysis in this paper is based on labor markets defined by the 1985 classification of county centers. In the trade-off between achieving a higher level of homogeneity across locations and maintaining a large 
enough sample size in our analysis, we restrict our sample to cities and towns with a 1985 population higher than 10,000. This leads to 342 county centers.

We conduct our analysis across county centers instead of whole counties due to several reasons. First of all, in many counties, the rural population - which is mostly engaged in agriculture and, therefore, do not compete in the same labor market with the dwellers of the major city or town in that county -make up a significant fraction of total population. In addition, some counties include other towns that are quite far away from the country center; and, the residents of these other towns within the same county would not compete in the same labor market in Turkey in 1985 as commuting for work to a different town was very unlikely, if possible, at that time. In fact, 44 percent of the total country population in 1985 lived in either villages or towns that were not country centers - which we exclude. Major cities which house more than one county center are treated as unified metropolitan areas. In 1985, there were three such cities - Istanbul, Ankara, and Izmir - with a population above one million.

The Censuses report the place of residence five years ago, which refers to the province of residence for internal migrants and non-migrants, and the country of residence for those who moved internationally. This allows the identification of repatriates in the 1990 Census. Repatriates are defined as those who resided in Bulgaria in 1985, but in Turkey in 1990 - who are virtually all 1989 repatriates. In addition, Censuses report the place of birth information, which allows the identification of earlier repatriates who were born in Bulgaria but were residing in Turkey in 1985. We call this group "earlier repatriates" in the rest of the paper.

Table 1 presents the distribution of the percentage increase in the labor force due to the inflow of repatriates across the 342 cities and towns in our sample. Out of these locations, 243 received no repatriates. In 68 of the remaining 99 locations, the labor supply shock due to repatriates was 1 percent or less. Repatriates in these 68 locations represented 9.8 percent of all repatriates. About half of the repatriates were located in 17 cities and towns where they represented a labor supply shock of 1 to 2 percent. In the remaining 14 locations, repatriates caused much larger increases in the labor supply; in fact, in 8 locations the surge in the labor force was above 4 percent; and in 2 locations, it was above 10 percent. 
Table 2 provides further detail by listing the 20 cities and towns, as well as their key characteristics, for which the percentage growth in the labor force due to 1989 repatriates was the highest. All of these 20 cities and towns are located in provinces in Western Turkey, which covers Istanbul, West Marmara, Aegean, and East Marmara regions (NUTS1 regions 1 to 4 ). In fact, all of the 31 cities and towns where the rise in the labor force was more than 1 percent and 67 of the 99 cities and towns that received some repatriates are in these four regions. Western Turkey is an area with a more homogenous economic structure and level of development. Importantly, however, within this region there is also large variation in repatriate shocks in the labor force across locations. In fact, in many cases, while one county center does not have any repatriates, a neighboring county center has a significant number of repatriates due to historical patterns and government involvement in these patterns.

Table 2 also allows a comparison of the ratio of earlier repatriates to non-repatriates in the 1985 labor force and the rise in the 1990 labor force due to the 1989 repatriates across the 20 cities and towns with the highest repatriate shock in 1989. The numbers indicate a very high level of correlation in the settlement patterns of earlier repatriates in 1985 and of repatriates in 1990. The final column in Table 2 shows the 1985 population of the 20 cities and towns with the largest repatriate shock. Several of these top-20 locations are small cities with a population below 100,000, which is representative of the size of the urban centers in Turkey in 1985. At the same time, the city with the third largest immigrant shock-where the surge in the labor force was above 7 percent - was the fifth largest city of Turkey in 1985 with a population of 620,000 (Bursa); and, the top 20 cities and towns include other big cities like Eskisehir and Izmir.

Table 3 presents a comparison of the means of certain characteristics of repatriates and non-repatriates by gender among labor force participants. Repatriate men are, on average, about two and a half years older than non-repatriate men, and repatriate women are about two years older than non-repatriate women. However, the key difference between repatriates and non-repatriates is in terms of educational attainment. Non-repatriate men are much more likely to have low levels of education (primary school or less) whereas both repatriate men and women are much more likely to have junior-high or high school level education. In fact, while more than 80 percent of both male and female repatriates are either junior- 
high or high school graduates, less than 30 percent of non-repatriate men have this level of this educational attainment. A much larger fraction of non-repatriate women are university graduates due to the much higher labor force participation rate for women with university degrees compared to other women in Turkey. We investigate in the paper whether this difference in the relative skill composition of immigrants leads to differential labor market impacts on the native-born skill groups.

Table 3 shows quite favorable labor market outcomes for repatriates. Both male and female repatriates have a higher participation rate than their non-repatriate counterparts in particular, female repatriates. In addition, female repatriates have a lower unemployment rate than female non-repatriates across Turkey. However, these favorable outcomes for repatriates are partly a result of the differences in the location of residence of repatriates and non-repatriates. When the sample is restricted to Western Turkey (NUTS1 regions 1 to 4), where most repatriates settled, the unemployment rate of male repatriates, at 9.7 percent, is in fact higher than that of male non-repatriates, at 6.8 percent. Nonetheless, the lower unemployment rate for women and higher participation rates for both men and women for repatriates vis-à-vis non-repatriates persist.

\section{$5 \quad$ Empirical Model and Estimation Strategy}

In order to assess the impact of immigration on unemployment, the following empirical specification is used:

$(\text { nonrepat unemp rate })_{i t}=\alpha+\beta(\text { repatriate } / \text { non_repatriate })_{i t}+X_{i t} \Gamma+\mu_{i}+\gamma_{t}+u_{i t}$.

The dependent variable in (1) is the unemployment rate among non-repatriates in location $\mathrm{i}$ at time t. ${ }^{3}$ The key independent variable is the ratio of repatriates to non-repatriates in the labor force in location $\mathrm{i}$ at time $\mathrm{t}$, which measures the change in the labor supply due to repatriates in location i at time t. ${ }^{4}$ Other controls, X, include the shares of age-groups (16-

\footnotetext{
${ }^{3}$ Here, non-repatriates exclude repatriates who arrived in Turkey from Bulgaria within the last five years, but include earlier repatriates.

${ }^{4}$ Repatriates are those immigrants enumerated in 1990 Census who arrived from Bulgaria over the past five years. Almost all of the repatriates in 1990 are those that arrived in Turkey in 1989.
} 
25, 26-35, 36-45, 46-55, 56-65) by gender, five education groups (less than primary, primary, junior high, high school, university graduates) and 9 sectors of employment. In (1), stands for location fixed effects, for time effects, and is the error term.

The variables in (1) are available in our data for two different time periods, namely 1985 and 1990. This allows us to use panel-data estimation methods; in particular, we estimate the following first-differenced equation

$$
\Delta(\text { nonrepat unemp rate })_{i}=\gamma+\beta \Delta(\text { repatriate } / \text { non_repatriate })_{i}+\Delta X_{i t} \Gamma+\Delta u_{i t} \text {, }
$$

where $\Delta(x)$ denotes the difference between the 1990 and 1985 values of variable x. Here, the key parameter of interest, $\beta$, measures the effect of the change in the ratio of repatriates to non-repatriates in the labor force from 1985 to 1990 on the change in the unemployment rate of non-repatriates from 1985 to 1990 across various cities and towns in Turkey. Since there are few repatriates in 1985 who arrived within the last 5 years, our key parameter of interest virtually measures the effect of the 1989 repatriates.

The differencing in (2) eliminates the time-invariant location characteristics that could be correlated with the share of repatriates in the labor force. However, the change in economic conditions from 1985 to 1990 could be quite different across various regions in Turkey; in particular, the trend in the unemployment rate (independent of immigration) could vary across regions. In fact, while the unemployment rate in the cities and towns in our sample fell by 1.64 and 0.86 percentage points in the Western Black Sea and Central Anatolia regions, respectively, from 1985 to 1990; the unemployment rates in Northeast Anatolia and Southeast Anatolia increased by 1.6 and 2.7 percentage points, respectively, during the same period. (The share of repatriates in all these regions was less than 0.1 percent of the labor force.) In order to account for such time-variant location effects, at least partially, we add province-level fixed effects (67 province fixed-effects over the 342 towns/cities) to $(2){ }^{5}$ We estimate this equation using weighted least-squares: the weights are equal to $\left[1 /\left(1 / w_{85}+1 / w_{90}\right)\right]$ where $w_{t}$ denotes the size of the labor force at year $\mathrm{t}$.

Although the 1989 influx of repatriates was politically driven, the location choice of these migrants could still be economically motivated; for example, they could choose to settle in

\footnotetext{
${ }^{5}$ Hunt (1992) also introduces region specific dummies to the estimation of the first differenced equation.
} 
a certain city because the economy is booming there. In that case, our key variable of interest, the ratio of repatriates to non-repatriates in the labor force, would be endogenous. Therefore, we use an instrumental-variables estimation method where the change in the ratio of repatriates to non-repatriates in the labor force from 1985 to 1990 in (2) is instrumented by the ratio of earlier repatriates to non-repatriates in the labor force in 1985 at that location.

\subsection{Validity of the Instrument}

The validity of our instrument requires that the ratio of earlier repatriates to non-repatriates across locations be unrelated to the change in unemployment rate from 1985 to 1990 in any way other than through its effect on the number of 1989 repatriates. Next, we present historical evidence, as well as evidence from our data, supporting the validity of the instrument.

The key concern as to the validity of our instrument is that if earlier repatriates chose their locations based on economic circumstances, we could expect their location of residence in 1985 to be related to the change in the economic conditions from 1985 to 1990 in that location. Previous studies that use the stock of immigrants as an instrument for later immigrants ignore this potential threat to instrument validity. However, our context has peculiar features that yield the initial location of residence of earlier repatriates likely to be independent of economic circumstances at the time of settlement. As explained in detail in Section 2, earlier flows of repatriates from Bulgaria were actively settled in by the Turkish government not only by building housing for them but also by choosing the provinces that they would settle in (Figures 1 and 2). The state chose these provinces according to their similarity to the original homeland of the repatriates and according to a policy of populating relatively vacant areas; therefore, the location choice was not based on economic conditions.

Although the Turkish government's involvement in the settlement of earlier repatriates was large, it is certainly possible that these earlier repatriates changed their locations before the arrival of 1989 repatriates substantially according to the differences in the economic conditions across these locations. We check for this possibility by comparing the settlement patterns of earlier repatriates at the time of arrival and their location of residence in 1985. As indicated earlier, the entire 1950-51 cohort was subject to a settlement policy. For this cohort 
we know how many were allocated to each of the 67 provinces in Turkey. ${ }^{6}$ The provincial shares of this migrant cohort according to the settlement plan (x) are compared to the provincial shares of all migrants from Bulgaria observed in the 1985 Census (y) through a simple regression of $\mathrm{y}$ on $\mathrm{x}$. The fitted regression line is presented in Figure 3a in Appendix for all 67 provinces and in Figure 3b for the 14 provinces where the provincial share of repatriates is at least 1 percent. These figures indicate a very strong correlation between the settlement provinces of the cohort arriving over 1950-51 and those of the migrants observed in 1985. For the first regression referring to Figure 3a, the R2 of the regression is 0.66 , while for the second referring to Figure $3 \mathrm{~b}$ it is 0.72 . These results indicate that most of the earlier repatriates stayed in their original areas of settlement and those that were not governed by a settlement policy (such as the 1968 cohort) chose locations that are very similar to earlier cohorts. Therefore, the settlement policy by the state was very effective in determining the resulting locations of ethnic Turks from Bulgaria.

Another approach we take to examine whether repatriates relocated from their initial settlement locations due to economic conditions is as follows. If the location of residence of earlier repatriates responded to the changes in economic conditions before 1985 we would expect an association between their locations of residence and economic conditions across locations in 1985. This would pose a threat to instrument validity because we would expect the change in economic conditions from 1985 to 1990 to be correlated with the change in economic conditions before 1985 leading to an association between the location of residence of earlier repatriates and the change in economic conditions from 1985 to 1990 . We check for this possibility by running a regression of the ratio of repatriates to non-repatriates in 1985 on the unemployment rate over the cities and towns in our sample using the 1985 data, while also controlling for the composition of the labor force in terms of age and gender, education, and sector of employment as well as the population of locations and province dummies. However, we do not find any evidence of an association between the unemployment rate in 1985 and the ratio of repatriates to non-repatriates in 1985.

Finally, it could be the case that the initial locations of earlier repatriates later happened to be the economically thriving parts of Turkey, even though these initial locations were not

\footnotetext{
${ }^{6}$ This initial settlement information is available only at the provincial level.
} 
chosen by the government according to any economic criteria. If this was the case, we would expect the location choice of internal migrants in Turkey, as well as international migrants, to be correlated with the residence of earlier repatriates in those locations. In order to test the existence of such a correlation, we regress the increase in the labor supply due to 1989 repatriates and the share of internal and international migrants (excluding repatriates) who migrated between 1985 and 1990 on the ratio of repatriates to non-repatriates in 1985 and the unemployment rate in 1985, as well as the standard set of control variables used above. As can be seen from the estimates of these regressions presented in Appendix Table 3 , while the ratio of earlier repatriates has a strong influence on the settlement patterns of 1989 repatriates, there is no evidence of an association between the location choice of other migrants and the ratio of earlier repatriates across locations for any sample. On the other hand, the location choice of other migrants responds to the unemployment rate whereas there is no such evidence for the location choice of the 1989 repatriates. These confirm our assertion that while it was the presence of earlier repatriates that largely determined the location of choice of 1989 repatriates, economic conditions as indicated by the unemployment rate variable were the key driving factor in the location decision of other migrants.

\subsection{Propensity-Score Matching}

If we had the perfect instrument, that is, the instrument had zero correlation with the error term in (2) - the difference between the error terms in 1990 and 1985 - there would be no need to worry about the overlap in covariate distributions of the treatment and comparison groups. Even though we provide supporting evidence for the validity of our instrument, in samples where the covariate balance between the treatment and control groups is poor, it becomes more likely that the instrument will be contaminated by some unmeasured factors in which treatment and control groups are not comparable. In other words, the conditional independence assumption for the instrument is more likely to fail when the imbalance in the characteristics of the treatment and control groups is greater. Therefore, we care about the quality of the match between the treatment and comparison groups as much as we care about the quality of our instrument.

In fact, there remain a few concerns about omitted variable bias in our context when the 
treatment and comparison groups do not match well. First, the trends in the unemployment rates of the treatment and comparison groups could differ. ${ }^{7}$ Second, between 1985 and 1990, other events that occur in the treatment cities but not in the comparison cities could also explain our findings. Thus, the construction of a matched sample by dropping comparison locations that are significantly different from treatment locations is critical to reduce any potential bias due to omitted covariates. ${ }^{8}$ In fact, Imbens and Wooldridge (2009) argue that by constructing a sufficiently well balanced matched sample, one may be able to obtain more credible and robust estimates relative to those that would be obtained from the original sample. ${ }^{9}$ In this sense, several studies use matching in combination with other estimators; for example, in the program evaluation literature, matching is used first to establish comparison groups followed by a difference-in-difference estimation to obtain impact estimates of the program (see Heckman et al., 1997, 1998; Smith and Todd, 2005; Behrman et al., 2009). Griffith and Neely (2009) is another example, outside of the program evaluation literature, that combines matching with other estimators. Abadie (2005) extends this estimation procedure by allowing for a more parsimonious parametric structure and by accommodating multilevel treatment variables, with repeated cross-sectional data.

The previous literature that utilizes geographic variation in immigrant concentration in order to assess the labor market impacts of immigration adopts an instrumental variable estimation strategy only, under the conditional independence assumption. However, this approach ignores any potential bias in estimates that could arise from omitted variables due to poor matches between treatment and comparison groups. Of course, constructing a well-balanced matched sample requires a comparison sample that is much larger than the treatment sample. While this is a serious constraint for earlier studies, the context of this study offers a large comparison sample that allows us to pay more attention for constructing comparison groups that are sufficiently well balanced in terms of covariates with the treatment group. A potential concern with our matching approach is that there

\footnotetext{
${ }^{7}$ The province dummies in the specification would partially take care of this problem.

${ }^{8}$ The covariate imbalance between the treatment and control groups is the very reason that LaLonde (1996) is criticized by the following work.

${ }^{9}$ The importance of selecting appropriate comparison groups in studies that exploit natural experiments is also discussed in Meyer (1995) and Angrist and Krueger (1999).
} 
could be an efficiency loss due to the fall in the variation in the independent variable; however, the estimation results reveal that this is not a problem in our study.

For this purpose, we regress the ratio of 1989 repatriates to non-repatriates in the labor force on the 1985 values of population, unemployment rate as well as the composition of the labor force in terms of age, gender, education, and sector of employment; province dummies are also included in this regression. Using the estimated coefficients from this regression, we generate the predicted values of the share of 1989 repatriates - what we call propensity score - for each location in our sample. This propensity score basically illustrates what the expected ratio of the 1989 repatriates in the labor force would be at each location given its 1985 characteristics. We group the locations in our sample into deciles according to this propensity score. Table 4 illustrates the number of locations in the treatment and comparison groups for each decile under various definitions of the treatment group. When the treatment group is defined as the cities and towns where the increase in the labor force due to the 1989 repatriates is more than 1 percent, panel (a) of the table shows that of the 31 treatment group locations, 26 are in the top decile of the propensity score, 3 are in the second highest decile, 1 is in the third highest centile, and 1 is in the fourth highest decile. According to this definition of treatment group, of the 34 locations in the highest decile of the propensity score, 26 are in the treatment group - these locations were expected to receive a lot of repatriates and they did — and 8 locations are in the comparison group - these locations were also expected to receive a lot of repatriates but they did not. Note that in our analysis, we do not use an arbitrary definition of the treatment group; it is done here only for the illustration of the idea.

Our approach is similar to that of Dehejia and Wahba (1999), who divide the propensity score into intervals after dropping the observations with a propensity score lower than that of the treatment city with the lowest propensity score, and then estimate the treatment effect for the treated for each propensity-score interval separately, and finally aggregate these effects. ${ }^{10}$ However, since almost all of our treatment cities are in the higher propensity-score intervals, we focus our analysis on these intervals only. In fact, our method follows what Rubin (2006) proposes: we sub-classify the sample based on a single measure of multivariate

\footnotetext{
${ }^{10}$ Dehejia and Wahba (2002) examine the effects of using different matching algorithms.
} 
characteristics of the locations (propensity-score) and conduct our analysis according to this sub-classification separately. ${ }^{11}$

Table A1 in the Appendix illustrates the effect of our propensity-score matching method on the geographical distribution of our sample by comparing the number of locations in each NUTS-1 level region for the top-30 percentile of the estimated propensity score and for the total sample. Of the 102 locations in the top-30 percentile, 72 are in the first four NUTS-1 regions, which received the largest chunk of the 1989 repatriates; and, of the 31 locations in West Marmara (NUTS-1 region 2), 27 lie in the top 30 percentile of the estimated propensity-score. ${ }^{12}$

\section{Results}

This section presents the estimation results of the unemployment rate equation for nonrepatriates by gender. As can be seen from Table 3, while there is a substantial gender gap among non-repatriates in terms of labor market characteristics like labor-force participation and sector of employment, as well as educational attainment, there is much less difference between repatriate men and women in these characteristics. For instance, the gender gap in the labor force participation rate is 67 percent for non-repatriates, but 32 percent for repatriates. Moreover, while the educational distributions of repatriate men and women in the labor force are very similar, there is a big difference between those of non-repatriate men and women - non-repatriate women who are in the labor force are much more likely to be highly educated. Thus, we would expect the level of substitutability between men and women to be much higher among repatriates than non-repatriates. Therefore, we estimate the impact of the repatriate shock - taking repatriate men and women as a single group -

\footnotetext{
${ }^{11}$ Rosenbaum and Rubin [1984] discuss the advantages of this method relative to a single analysis that tries to adjust for the differences across groups. A key advantage is that model-based adjustment on matched samples is more robust to departures from the true underlying model (Rubin, 1979).

${ }^{12}$ The locations with a high estimated propensity-score that are not in the first four NUTS-1 regions include cities and towns like Batman, Gaziantep, Karabük, Kayseri and Kırıkkale - which are important manufacturing centers, as are several cities and towns where many repatriates settled in.
} 
on male and female non-repatriates separately. ${ }^{13}$

Table 5 presents the OLS and 2SLS estimation results of the unemployment rate equation for three different samples of cities and towns defined based on restrictions on the 1985 population. In panel (a), where the sample includes cities and towns with a 1985 population greater than 10,000, both OLS and 2SLS indicate that the increase in labor supply due to the 1989 repatriates in fact increased the unemployment of male non-repatriates, but not that of female non-repatriates. In the first row of panel (a), where the sample includes all 342 cities and towns, the estimated 2SLS coefficient for men is 0.263 and statistically significant only at the 10 percent level. As we restrict the sample to cities and towns with a higher propensity score in the following rows of panel (a), the estimated impact of repatriates gradually increases. ${ }^{14}$ In fact, in the last row of panel (a), where the sample is restricted to the locations with a propensity-score that is in the top-30 percentile, the estimated 2SLS coefficient is 0.417 - which is more than 50 percent higher than the initial estimate in the first row for the whole sample.

A few county centers were already large metropolitan areas in 1985; therefore, defining these centers as a single labor market may not be very appropriate. Moreover, of the population in the 342 cities and towns in our sample, about 36 percent lived in these three cities only in 1985. Hence, in panel (b) of Table 5, we exclude these three metropolitan areas from our sample in panel (a). The estimates with this sample also point out a negative impact of repatriates on employment of non-repatriate men but not women. The estimated coefficients for men are slightly larger in panel (b); however, the patterns are very similar to those in panel (a). The estimated 2SLS coefficient for men in the first row, 0.282, increases all the way to 0.502 in the last row, which includes the cities and towns in the top-30 propensity score. (All the estimated coefficients for men are statistically significant at the 5 percent level, except for the smallest sample in the last row where the statistical significance is at

\footnotetext{
${ }^{13}$ The effects of the male repatriate shock only are also examined in Section VI.II, where we conduct robustness checks.

${ }^{14}$ There are two opposing effects on the magnitude of the standard error as we increase the restriction on the propensity score. On one hand, as argued by Rosenbaum and Rubin (1983), the variance of the average treatment effect decreases as the covariates of treatment and comparison groups become more similar. On the other hand, the fall in the sample size has a countervailing effect.
} 
the 10 percent level.)

Finally, in panel (c) of Table 5, we restrict the sample to larger cities and towns by imposing a minimum population restriction of 25,000 but also maintaining the exclusion of three largest metropolitan areas. This gives us the most homogenous sample in terms of population; moreover, it increases the comparability of our findings to similar area-studies in the US context conducted for metropolitan standard areas. The estimates with this sample also show a negative employment impact of repatriates on male non-repatriates. However, the magnitude of the estimated impact is larger with this sample. At the same time, the gradually increasing pattern in the estimated coefficient with successive restrictions on the propensity-score still holds: the estimated 2SLS coefficient in the first row including 150 cities and towns, 0.484, increases to 0.744 when the sample is restricted to 90 cities and towns with the top-60 propensity score in the last row. The coefficient estimate for the impact of repatriates on the unemployment of non-repatriate women is positive in panel (c), unlike those in panels (a) and (b); however, they are still statistically insignificant. ${ }^{15}$

Table A3 in the Appendix displays the first-stage estimation results as well as the partial F-statistics for the same set of 2SLS estimations in Table 5. For all samples, we find a very strong effect of earlier repatriates on the geographical distribution of 1989 repatriates: in all samples, a ten-percentage point increase in the ratio of earlier repatriates to non-repatriates in 1985 increases the ratio of 1989 repatriates to non-repatriates by more than 5 percentage points. Moreover, the partial F-statistics are much larger than the typical values suggested in the IV-estimation literature. ${ }^{16}$

In essence, we find that the 1989 repatriates substantially increased the unemployment of non-repatriates. A 1-percent increase in the labor supply due to repatriates, which is roughly equivalent to the repatriate shock in the cities and towns with a population greater than

\footnotetext{
${ }^{15}$ In an earlier version of the paper (Aydemir and Kirdar, 2011), the analysis presented in Table 5 was conducted on other samples defined by different restrictions on the 1985 population. Our key findings hold also with a sample of 613 cities and towns with a population above 2,000, with a sample of 509 locations with a population above 5,000, as well as with a sample of 184 locations with a population above 20,000.

${ }^{16}$ We also conduct our instrument validity checks that are based on regression analysis - outlined in the last two paragraphs of Section V.I - according to the propensity-score restrictions in Table 5. The conclusions in Section V.I about the validity of our instrument hold for all of these propensity-score restrictions as well.
} 
10,000 that are in the top-40 percentile propensity score, brings about a 0.4 percentage point increase in the unemployment rate. Put differently, we find that for every 10 immigrants that enter the labor market, 4 natives lose their jobs and 5 new jobs are created across the cities and towns with a population greater than 10,000 (because roughly 9 of the 10 repatriates who enter the labor force are employed). This new job creation implies that either the real wage rate went down or there was a rise in labor demand. The effect of 1989 repatriates on unemployment was even stronger in larger cities and towns. Across cities and towns with a population between 25,000 and $1,000,000$, for every 10 immigrants that enter the labor market, roughly 6 natives lose their jobs and 3 new jobs are created.

This impact is much higher than those reported in Card (2001) - who finds that a 1 percent increase in share of immigrants in the US decreases native employment by 0.1 to 0.2 percentage points - and in Dustmann et al. (2005), who finds that a 1-percent increase in the labor supply in the UK decreases the employment rate by 0.07 percentage points. On the other hand, our estimate is similar to that in Borjas et al. (1996), who find that a 1 percentage point increase in the share of immigrants in the US increases the unemployment rate by 0.5 percentage points. Angrist and Kugler (2003) estimate an even larger effect in their cross-country study in the European setting: they find that 100 immigrants take 83 native jobs, which is larger than even our estimate at larger locations.

Our other key finding is that as the covariate balance between the treatment and comparison group is improved through matching, the estimated coefficient becomes larger. This finding holds for all three samples that we use in our analysis in Table 5. The reason for this fact is illustrated in Table 6 , where the balance in covariates between the treatment and comparison groups is given for the nationwide sample as well as for various samples defined according to the estimated propensity score. (The treatment group for purposes of this table is defined as those locations where the ratio of repatriates to non-repatriates in the labor force exceeds 2 percent. The cities and towns in the treatment group are the same in all samples displayed in Table 6, regardless of the propensity-score restriction.) Treatment and comparison group locations in the nationwide sample differ markedly in several features; for example, the mean unemployment rate for the treatment group is 8.2 percent whereas it is 13.7 percent for the comparison group. (This difference is statistically significant at the 
1 percent level.) Moreover, there are significant differences between the two groups in the shares of education groups and sectors of employment. For instance, while the percent in agriculture and the percent in manufacturing are 6.2 and 27.3, respectively, for the treatment group, they are 17.4 and 15.1, respectively, for the comparison group. However, as can be seen from Table 6, as we gradually restrict the sample to higher propensity-score cities and towns, the covariate balance between the treatment and comparison groups also gradually improves. In the final top-20 percentile sample, there remains no statistically significant difference in the unemployment rate and the share employed in manufacturing between the treatment and comparison groups; furthermore, several other covariates match better. It is also important to note that the gradual improvement in the covariate balance in Table 6 is consistent with the gradual change in the estimated coefficients in Table 5.

This improvement in the match between the observed characteristics of the treatment and comparison groups as we restrict the sample based on the estimated propensity score implies that there also remains less difference between the unobserved characteristics of the treatment and comparison groups. The bias resulting from the unobserved characteristics in which our treatment and comparison groups are not comparable causes an underestimation of the impact of repatriates on the unemployment rate in the nationwide sample (for both OLS and 2SLS estimations).

In general, for a given panel in Table 5 the rise in the estimated impact of repatriates on non-repatriate unemployment as we restrict the sample to higher propensity scores could also arise from a different reason: the effect of repatriates on non-repatriate unemployment could be heterogenous across treatment locations. However, this could not be the reason in our study because, as can be seen from Table 4, as we slice the sample according to our estimated propensity score, the cities and towns with high treatment intensity are always kept in the sample; only the cities and towns with low treatment intensity, many of which did not receive any 1989 repatriates, are eliminated. On the other hand, the higher estimated impact for larger cities and towns in panel (c) compared to those in panels (a) and (b) could result from heterogeneity in the employment effect of repatriates by city size, as well as from the improvement in the match between the characteristics of treatment and comparison groups. (Note that the sample in panel (c) is more homogenous). Put differently, the difference in the 
impact estimates across various panels in Table 5 could result both from heterogeneity in the repatriate effects across locations and from improvement in the covariate balance between the treatment and comparison groups, whereas the improvement in impact estimates within a single panel as we change the propensity-score restriction could take place only due to the latter reason.

If the 1989 repatriates chose their location of residence in part due to economic conditions, we would expect OLS estimates to underestimate the true impact of repatriates compared to 2SLS estimates. However, the OLS and 2SLS estimates in Table 5 are very similar, regardless of the restrictions via the estimated propensity score, which implies that economic conditions did not play a significant role in the location of residence decision of the 1989 repatriates. The very high level association in the settlement patterns of 1989 repatriates and earlier repatriates across locations, illustrated in Table A4, attests to this fact.

\subsection{Results by Demographic Groups}

The results in Table 5 show that while there is a significant impact of repatriates on the unemployment rate of non-repatriate men, no such effect is observed on non-repatriate women. Thus, in the remainder of our analysis across subgroups of non-repatriates, we restrict the analysis to men only.

Table 7 presents the impact of repatriates on different groups of male non-repatriates by education. (While the dependent variable - the unemployment rate of non-repatriates is by education, the right-hand-side variable for the repatriate shock is for the total labor force. As shown earlier in Table 3, repatriates are a much more homogenous group in terms of educational attainment.) As can be seen from Table 7, there is evidence that repatriates increase the unemployment of male non-repatriates who are primary school graduates and junior-high or high school graduates, whereas there is no evidence of an effect of repatriates on the unemployment of male non-repatriates who have very low (less than primary) or very high (university) education levels. The effect is especially strong for non-repatriates who are junior-high or high-school graduates; in fact, in smaller samples with stronger restrictions on the estimated propensity-score, the effect on this group is almost twice as big as the effect on non-repatriates with a primary school diploma. This strong impact on junior high 
and high-school graduates is not surprising because, as illustrated in Table 3, a large share of 1989 repatriates are also junior-high and high school graduates. Non-repatriates and repatriates with similar skill levels are likely to be substitutes in production. Therefore, the labor market impact of immigration is larger on non-repatriate skill groups in which repatriates are concentrated. Our previous finding that the impact of repatriates becomes larger as the locations are restricted to more homogenous areas is also confirmed by the analysis by education. The 2SLS coefficient estimate for the junior-high and high school group gradually increases from 0.384 to 0.596 from the first to the last row in panel (c).

Within education groups, it is also interesting to find out whether different age groups are equally affected by the repatriate supply shock. Table 8 estimates the same relationship for non-repatriate men who are primary school graduates in panel (a) and who are junior-high or high-school graduates in panel (b), but now distinguishes among age groups as well. The results show that the repatriates have a large impact on young workers (aged 16 to 30) in both education groups, whereas there is no evidence of an impact on older workers (aged 31 to 65) in either education group. The effect of a 1 percent increase in the labor force due to repatriates on the unemployment rate of young workers is almost a full percentage-point among the junior-high and high school graduates and about 0.6 percentage-points among the primary school graduates. Given the fraction of primary school graduates and junior high or high-school graduates in the population and their unemployment rates, these estimates imply that for 100 repatriates that enter the labor force, roughly 33 young primary-school graduates and 24 young junior-high or high-school graduates become unemployed. These estimates by age and education imply a larger total effect than the estimate for the total nonrepatriate population, given in Table 4, which implies that roughly 40 non-repatriates become unemployed for 100 repatriates that enter the labor force. This finding of larger impact estimates for certain education and age groups is in line with larger estimates reported for skill groups that face larger immigrant induced supply shocks in the North American context (for instance, Borjas [2003], Aydemir and Borjas [2007]). 


\subsection{Robustness Checks}

Our analysis so far already included one robustness check: we examined the effect of repatriates across cities and towns with various restrictions on their population. In this section, we conduct further robustness of our findings using different empirical specifications - using employment rate and labor force participation as dependent variables - and different variable definitions, and by examining the potential effects of internal and other international migrants, as well as measurement error in the estimation. ${ }^{17}$

\subsubsection{Effects on Employment Rate and Labor Force Participation}

We also estimate an employment-rate equation - where the control variables are the same as those in the unemployment-rate equation, as well as an equation for labor force participation. Table 9 presents the estimation results of the employment-rate equation. For men, the magnitudes of both the OLS and 2SLS coefficient estimates are very similar to those estimated for the unemployment-rate equation in Table 5. However, statistical significance is lower due to larger standard errors; only in panels (b) and (c), we have evidence for an effect of repatriates on the employment rate of male non-repatriates. ${ }^{18}$ For women, the signs of the estimated effect of repatriates on employment are consistent in all panelsunlike those in Table 5. Moreover, the 2SLS coefficients are much more similar to those of men. Nonetheless, except for that for the top-40 propensity score sample in panel (b), the estimated coefficients for women are not statistically significant at the conventional levels. For women, we find the estimates of the employment-rate equation to be more reliable than the estimates of the unemployment rate equation in Table 5 because the denominator of the dependent variable in the unemployment-rate equation, labor force, takes small values for women in certain locations. Finally, our key finding that the magnitude of the estimated

\footnotetext{
${ }^{17}$ We also check for the robustness of our findings to the empirical specification used in the propensity-score estimation, as it is emphasized by Dehejia and Wahba (1999). Our findings are robust to this check.

${ }^{18}$ In fact, the results are not statistically significant for the nationwide sample in panels (b) and (c), but statistically significant for more homogenous samples in the lower rows. This is in accordance with the claim of Imbens and Wooldridge (2009) that estimation on samples that are well balanced in covariates leads to not only more robust but also more precise estimates.
} 
effect of repatriates becomes larger as we improve the overlap between the covariate distributions of the treatment and comparison groups holds for the employment-rate equation as well. For instance, in sample C, the 2SLS coefficient estimate for the nationwide sample, 0.362 , increases to 0.629 when the sample is restricted to the cities and towns in the top-30 percentile propensity-score.

The estimation results on the effect of repatriates on labor force participation of nonrepatriates are given in Table 10. The estimated effect on labor force participation of male non-repatriates is virtually zero in all samples. On the other hand, the estimated coefficients on labor force participation of female non-repatriates are much larger, in particular the 2SLS coefficients. However, none is statistically significant at the conventional levels, except for the top-40 percentile propensity score in panel (b). Here, the magnitude of repatriates' effect also becomes larger as we restrict the sample with cities and towns with higher propensity score.

Combining these findings on repatriates' effects on employment rate and labor force participation with those on unemployment rate, we can assert that there is strong evidence for a substantial level of transition from employment to unemployment status for non-repatriate men due to the arrival of repatriates in 1989; however, there was no change in the labor force participation of non-repatriate men. For non-repatriate women, there is suggestive evidence of exit from labor force participation, as well as fall in employment, due to the arrival of repatriates. These two events for non-repatriate women with the arrival of repatriates could be explained by a transition from employment to out-of-labor-force status, or more likely by simultaneous transitions from employment to unemployment and unemployment to out of labor force.

\subsubsection{Effects of Other Migrants}

The arrival of repatriates, through their impact on labor market prospects, may also affect the migration decisions of non-repatriates; for example, non-repatriates could become more likely to choose locations that are less affected by repatriates. ${ }^{19}$ Similarly, the arrival of

\footnotetext{
${ }^{19}$ There is no consensus in the literature whether native workers respond to immigration by moving to areas less affected from migration (see, e.g., Card 2001, Borjas 2006).
} 
repatriates could encourage the out-migration of non-repatriates living in locations that receive a high share of repatriates. Since the 1985 data do not include information on the county of residence 5 years ago, it is not possible to calculate the change in out-migration rates from 1980 to $1985 .^{20}$ However, the share of in-migrants (either internal migrants from other provinces or international migrants) that a location receives in the preceding 5 year interval is available both in 1985 and in 1990. We examine whether the arrival of 1989 repatriates influenced the settlement patterns of other in-migrants by running a differenced equation analogous to our unemployment rate equation where the dependent variable is the share of other male in-migrants across locations and the control variables are the same as those in equation (2). The estimation results are given in Table A4 in the Appendix. There is no evidence that the arrival of 1989 repatriates affected the arrival of other in-migrants across locations. This is not a surprise because as the repatriates arrived in 1989, there was little time for other in-migrants to respond by 1990.

\subsubsection{Different Variable Definitions}

It is possible that the negative impact that we estimate on the employment of non-repatriates is driven primarily from the negative impact of repatriates on the employment of earlier waves of repatriates. ${ }^{21}$ In order to check for this possibility, we drop earlier repatriates from our sample of non-repatriates and run the same estimations in Table 5. We find that this exclusion does not change our findings: the patterns of earlier findings persist and, in fact, the coefficient estimates are very similar in general (Table A5 in the Appendix).

Male repatriates could be closer substitutes to male non-repatriates than female repatriates. Therefore, we also examine the effect of the repatriate shock in the male labor supply only on the unemployment of male non-repatriates. As can be seen from Table A6 in the Appendix, the estimated effect is larger in all panels when the repatriate shock is defined for the male labor supply only. For instance, the 2SLS coefficient for the top-40 percentile

\footnotetext{
${ }^{20}$ If non-repatriates in locations that receive many repatriates responded by emigrating to other regions, we would underestimate the impact of repatriates.

${ }^{21}$ D'Amuri et al. (2010) find that while immigrants arriving in Germany in the 1990s had little impact on the employment of natives, they had a substantial adverse effect on the employment of earlier immigrants.
} 
propensity score is 0.555 in panel (a) compared to 0.397 in Table 5 , and is 0.636 in panel (b) compared to 0.436 in Table 5.

\subsubsection{Measurement Error}

Estimated labor market impacts of immigration are susceptible to measurement error in studies where the key independent variable is the size of the immigrant supply shock in a given labor market. Measurement error arises because this variable, often computed from a sample, involves sampling error. Aydemir and Borjas (2011) show that the resulting downward bias can be especially large in studies using the geographic variation in immigrant supply shocks to identify the impact of immigration. In this section, the extent of attenuation bias is computed for different samples presented in Table 5 using the back-of-the-envelope correction proposed by Aydemir and Borjas (2011). Appendix Table A7 presents the percent downward bias for men corresponding to the reported estimates in Panels (a), (b) and (c) of Table 5 .

In these samples, the largest bias is 10.5 percent. ${ }^{22}$ In panels (a) and (b), the attenuation bias falls as the sample is restricted to higher propensity percentiles. This is driven by the substantial increase in the average sample size as we move down to higher propensity score percentiles reducing the sampling error in the measurement of the immigrant supply shock. A similar decline is not observed in panel (c) as we move down because the increase in the average sample size is much more modest and there is an associated increase in the of the auxiliary regression leading to larger attenuation bias. Importantly, the decline in the attenuation bias in panels (a) and (b) is much more modest than the increase in the estimated coefficients reported in Table 5 as the sample is restricted to higher propensity score percentiles. This rules out attenuation bias as the explanation of the increase in the estimated coefficients. Moreover, although the attenuation bias does not decline as we move down in panel (c), the coefficient estimates reported in Table 5 increase substantially.

\footnotetext{
${ }^{22}$ The magnitudes of the attenuation bias in Table A7 are smaller than those reported in the US and Canadian contexts by Aydemir and Borjas (2011) primarily because of the larger average sample sizes and smaller $R^{2}$ of the auxiliary regression in this context.
} 


\section{Conclusion}

This paper uses the 1989 migration of ethnic Turks from Bulgaria in order to measure the employment effects of an exogenous increase in labor supply. The methodology is a differencein-differences regression framework where the cities and towns that receive migrants form the treatment group.

A key distinguishing feature of this study is that the canonical "Altonji-Card instrument" that we use is plausibly more exogenous than the norm because of the involvement of the Turkish government in the settlement of earlier waves of repatriates. Our setting is also peculiar in that there are a number of treatment cities and towns with variable treatment intensity; and in several locations, the rise in the labor force due to repatriates is about 5 to 10 percent. Moreover, this large immigration wave was realized only within a period of 3 months. Therefore, we claim that this large sudden burst of immigration where the settlement patterns of immigrants were largely determined by earlier government policies comes closer to an ideal natural experiment - compared to the previous studies taking this approach.

The analysis also differs from the previous studies on this topic utilizing natural experiments in the way that we construct a matched sample, based on an estimated propensityscore, that is sufficiently well-balanced in covariate distributions of the treatment and comparison groups. We argue that the combination of 2SLS estimation with a well-balanced matched sample reduces bias relative to the 2SLS estimation on the unbalanced original sample. Furthermore, the analysis is also unique among natural experiment studies on this topic in that it examines the employment impact of the increase in labor supply by skill groups.

When the analysis is carried out on the original sample that has poor covariate balance between the treatment and comparison groups, we find a small impact of immigrants on the unemployment of natives - which is similar to the findings of the previous literature utilizing natural experiments. However, as we improve the covariate balance between the treatment and comparison groups, the magnitude of the positive effect of immigrants on the unemployment of natives increases remarkably. The magnitude of the estimated impact is 
in fact quite large: across the cities and towns with a population above 10,000 in 1985, we estimate that a 10 percent increase in the labor supply due to repatriates causes about a 4 percentage-point increase in the unemployment rate of non-repatriates. This impact estimate is more than 50 percent higher than the estimate for the unbalanced sample. The estimated impact is even stronger across larger locations: a 10 percent increase in the labor supply due to repatriates brings about 6 to 7 percentage-point increase in the unemployment rate of non-repatriates living in cities and towns with a population between 25,000 and 1,000,000.

Across the various skill groups, the impact of immigrants is the strongest on the locals with similar educational characteristics and among younger locals. Among 16 to 30 year old natives with a junior high or high school diploma, a 1 percent increase in the labor supply due to repatriates causes almost a full percentage-point increase in the unemployment rate.

The magnitude of the impact of the immigrant labor supply shock on the employment of locals estimated in this paper is much larger than those reported in most previous studies. However, we observe employment outcomes fourteen months after the arrival of repatriates. Their long-term impact on non-repatriate employment may differ from the short-run impact as labor market adjustments occur, an issue that we cannot address because the available data do not allow the identification of repatriates and labor market conditions at a later period.

Two other studies, Angrist and Kugler (2003) and Glitz (2011), also find large employment effects of immigrant shocks and interpret their findings as the outcome of rigid labor market institutions. In fact, Glitz (2011) points out sticky wages as the underlying factor. However, in the late 1980s Turkish context, where real wages could easily go down due to very high inflation (despite any potential stickiness in nominal wages), sticky-wages is not a likely phenomenon. In general, in the developing country labor market context of Turkey, labor market institutions are much less rigid. Nonetheless, there are certain characteristics of the Turkish repatriates from Bulgaria as well as the Turkish labor market that make a large employment effect likely.

Previous waves of ethnic Turks from Bulgaria preceding the 1989 flow enjoyed a very good reputation in the labor market as disciplined, hard-working workers. This reputation, as well as the facts that migrants arriving with the 1989 flow were fluent in Turkish and that 
there were no legal barriers to labor market access, helped 1989 repatriates in securing jobs. Moreover, the Turkish labor market displays a high level of worker turnover, and there is a large informal sector where the hiring and firing of workers by employers is relatively less costly than tightly regulated labor markets with strong labor rights. Therefore, it would be easier to replace incumbent workers with the repatriates. More importantly, since a high number of young workers with no work experience enter the labor-market as unemployed every month, hard-working and experienced repatriates from Bulgaria would be certainly preferred by employers. In fact, our results show that the impact was mostly on the young workers.

\section{References}

[1] Abadie, Alberto (2005). "Semiparametric Difference-in-Differences Estimators," Review of Economic Studies 72: 1-19.

[2] Altonji, Joseph, and David Card (1991). "The Effects of Immigration on the Labor Market Outcomes of Less-Skilled Natives," in J. Abowd and R. Freeman, eds.. Immigration. Trade and the Labor Market (Chicago, IL: University of Chicago Press), pp. 201-234.

[3] Amnesty International (1986). Bulgaria, Imprisonment of Ethnic Turks : Human Rights Abuses During the Forced Assimilation of the Ethnic Turkish Minority. London, Amnesty International Publications.

[4] Angrist, J.D. and Kugler, A. (2003). "Protective or Counter-Productive? Labor Market Institutions and the Effect of Immigration on EU Natives," The Economic Journal 113: F302-F331.

[5] Angrist, J.D. and Krueger, A.B. (1999). Empirical Strategies in Labor Economics, in O. Ashenfelter and D. Card, eds., Handbook of Labor Economics, volume 3A, pp. 12771366. 
[6] Aydemir A. and M.G. Kirdar (2011). "Quasi-experimental Impact Estimates of Immigrant Labor Supply Shocks: The Role of Treatment and Comparison Group Matching and Relative Skill Composition," CReAM Discussion Paper Series 1123.

[7] Aydemir A. and G. Borjas (2007). "Cross-Country Variation in the Impact of International Migration: Canada, Mexico, and the United States". Journal of the European Economic Association. Vol. 5, issue 4, p. 663-708.

[8] Aydemir A. and G. Borjas (2011). "Attenuation Bias in Measuring the Wage Impact of Immigration". Journal of Labor Economics, vol. 29, no. 1, pages 69-112.

[9] Behrman, J.R., Parker, S.W. and Todd, P.E. (2009). "Schooling Impacts of Conditional Cash Transfers on Young Children: Evidence from Mexico". Economic Development and Cultural Change 57(3): 439-77.

[10] Borjas, George J. (2003). "The Labor Demand Curve Is Downward Sloping: Reexamining the Impact of Immigration on the Labor Market," Quarterly Journal of Economics $118,1335-1374$.

[11] Borjas, George J. (2006). "Native internal migration and the labor market impact of immigration," Journal of Human Resources 41(2): 221-258.

[12] Borjas, G., Freeman R. and L. Katz (1992). "On the Labor Market Effects of Immigration and Trade," in G. Borjas and R. Freeman, eds., Immigration and the Work Force: Economic Consequences for the United States and Source Areas (Chicago, IL: University of Chicago Press) pp. 213-244.

[13] Borjas, G., Freeman R. and L. Katz (1996). "Searching for the Effect of Immigration on the Labor Market," American Economic Review, LXXXVI, 246-251.

[14] Borjas, G., Freeman R. and L. Katz (1997). "How Much Do Immigration and Trade Affect Labor Market Outcomes?" Brookings Papers on Economic Activity 1: 1-67.

[15] Boustan L.P., Fishback P.V. and S. Kantor (2010). "The Effect of Internal Migration on Local Labor Markets: American Cities during the Great Depression," Journal of Labor Economics 28: 719-746. 
[16] Card, David (1990). "The Impact of the Mariel Boatlift on the Miami Labor Market," Industrial and Labor Relations Review, XLIII, 245-257.

[17] Card, David (2001). "Immigrant inflows, native outflows, and the local 1abour market impacts of higher immigration,". Journal of Labor Economics 19(2): 22-64.

[18] Card, D. and A. Krueger (1994). "Minimum Wages and Employment: A Case Study of the Fast-Food Industry in New Jersey and Pennsylvania," American Economic Review 84(4): 772-93.

[19] Carrington, William, and Pedro deLima (1996). "The Impact of 1970s Repatriates from Africa on the Portuguese Labor Market," Industrial and Labor Relations Review, XLIX, $330-347$.

[20] Cortes, P. (2008). "The Effect of Low-skilled Immigration on US Prices: Evidence from CPI Data," Journal of Political Economy, 116(3), pp. 381-422.

[21] D'Amuri F., Ottaviano G. and G. Peri. (2010). "The labor market impact of immigration in Western Germany in the 1990s," European Economic Review 54: 550-570.

[22] Darby, Michael R., J. Haltiwanger, and M. Plant (1985). "Unemployment Rate Dynamics and Persistent Unemployment under Rational Expectations," American Economic Review 75(4): 614-637.

[23] Dehejia, R.H. and S. Wahba (1999). "Causal Effects in Nonexperimental Studies: Reevaluating the Evaluation of Training Programs," Journal of the American Statistical Association 94(448): 1053-62.

[24] Dehejia, R.H. and S. Wahba (2002). "Propensity Score Matching Methods for Nonexperimental Causal Studies," Review of Economics and Statistics 84(1): 151-161.

[25] Devlet Planlama Teskilatı (DPT) (1990). Bulgaristan'dan Türk Göçleri, DPT Sosyal Planlama Baskanlı̆̆ı Hizmete Özel Rapor, Ankara. 
[26] Doganay, F. (1996). Turkiye'ye Gocmen Olarak Gelenlerin Yerlesimi. Toplum ve Göç. II. Ulusal Sosyoloji Kongresi, Mersin, T.C. Basbakanlik Devlet Istatistik Enstitüsü : Sosyoloji Dernegi.

[27] Dustmann C., Fabbri F., and I. Preston (2005). "The impact of immigration on the British labour market," Economic Journal 115: F324-F341.

[28] Friedberg, R. (2001). "The Impact of Mass Migration on the Israeli Labor Market," Quarterly Journal of Economics 116(4): 1373-1408.

[29] Geray, C. (1962). Türkiye'den ve Türkiye'ye Göçler (1923-1961), Türkiye İktisadi Gelişmesi Araştırma Projesi, No: 4, Ankara.

[30] Glitz, A. (2011). "The Labor Market Impact of Immigration: A Quasi-experiment Exploiting Immigrant Location Rules in Germany," Journal of Labor Economics 30: 175213.

[31] Griffith, R. and A. Neely (2009). "Performance Pay and Managerial Experience in Multitask Teams: Evidence from within a Firm," Journal of Labor Economics 27(1): 49-82.

[32] Heckman, J. J., Ichimura, H. and Todd, P. E. (1997), "Matching as an Econometric Evaluation Estimator: Evidence from Evaluating a Job Training Programme", Review of Economic Studies, 64, 605-654

[33] Heckman, J. J., Ichimura, H. Smith, J. and Todd, P. E. (1998). "Characterizing Selection Bias Using Experimental Data," Econometrica 66(5): 1017-1098.

[34] Hunt, Jennifer (1992). "The Impact of the 1962 Repatriates from Algeria on the French Labor Market," Industrial and Labor Relations Review, XLV, 556-572.

[35] Imbens, G. and J. Wooldridge (2009). "Recent Developments in the Econometrics of Program Evaluation," Journal of Economic Literature 47: 5-86.

[36] Konukman, E. (1990). Tarihi belgeler isiginda büyük göç ve Anavatan : (nedenleri, boyutlari, sonuçlari). Ankara. 
[37] LaLonde, R. (1996). "Evaluating the Econometric Evaluations of Training Programs with Experimental Data," American Economic Review, 76(4): 604-20.

[38] LaLonde, Robert, and Robert Topel (1991). "Labor Market Adjustments to Increased Immigration," Immigration, Trade and the Labor Market, J. Abowd and R. Freeman, eds. (C Chicago, IL: University of Chicago Press), pp. 167-199.

[39] Mansour, H. (2010). "The effects of labor supply shocks on labor market outcomes: Evidence from the Israeli-Palestinian conflict," Labour Economics 17: 930-939.

[40] Meyer, B.D. (1995). "Natural and Quasi-experiments in Economics," Journal of Business and Economic Statistics 13(2): 151-61.

[41] Meyer, B.D., Viscusi V.K. and Durbin D.L. (1995) "Workers' Compensation and Injury Duration: Evidence from a Natural Experiment," American Economic Review 85: 32240.

[42] Pischke J.S. and J. Velling (1997). "Employment effects of immigration to Germany: An analysis based on local labor markets." Review of Economics and Statistics 79: 594-604.

[43] Rosenbaum, P.R. and D.B. Rubin (1983). "The Central Role of the Propensity Score in Observational Studies for Causal Effects," Biometrika 70(1): 41-55.

[44] Rosenbaum, P.R. and D.B. Rubin (1984). "Reducing Bias in Observational Studies Using Subclassification on the Propensity Score," Journal of the American Statistical Association 79(387): 516-24.

[45] Rubin D.B. (1979). "Using Multivariate Matched Sampling and Regression Adjustment to Control Bias in Observational Studies," Journal of the American Statistical Association 74: 318-28.

[46] Rubin D.B. (2006). Matched Sampling for Causal Effects. Cambridge and New York: Cambridge University Press. 
[47] Schoeni, Robert F. (1997). The effect of immigrants on the employment and wages of native workers: evidence from the 1970s and 1980s. Working Paper No. DRU-1408-IF, The Rand Corporation, Santa Monica, CA.

[48] Smith J.A. and P.E. Todd (2005). "Does Matching Overcome LaLonde's Critique of Nonexperimental Estimators?" Journal of Econometrics 125: 305-353.

[49] Taymaz E. and S. Özler (2005). Labor Market Policies and EU Accession: Problems and Prospects for Turkey. In B. Hoekman and S. Togan (eds.), Turkey: Towards EU Accession, The World Bank and CEPR, pp. 223-260.

[50] Tunalı İ. (2003). Background Study on Labor Market and Employment in Turkey. Prepared for the European Training Foundation.

[51] Vasileva, D. (1992). "Bulgarian Turkish Emigration and Return," International Migration Review 26(2): 342-352. 
Table 1 - The Distribution of the Change in the Labor Supply due to 1989 Repatriates across the Cities and Towns in the Sample

\begin{tabular}{ccc}
\hline $\begin{array}{c}\text { \% Increase in Labor } \\
\text { Supply due to Repatriates }\end{array}$ & $\begin{array}{c}\text { Number of } \\
\text { locations }\end{array}$ & $\begin{array}{c}\text { Percent of } \\
\text { repatriates }\end{array}$ \\
\hline 0 & 243 & 0 \\
$(0,1]$ & 68 & 9.8 \\
$(1,2]$ & 17 & 50.6 \\
$(2,3]$ & 3 & 1.2 \\
$(3,4]$ & 3 & 2.4 \\
$(4,5]$ & 3 & 2.2 \\
$(5,6]$ & 1 & 3.2 \\
$(6,7]$ & 1 & 0.8 \\
$(7,8]$ & 1 & 25.3 \\
$(10,11]$ & 2 & 4.6 \\
\hline Total & 342 & 100 \\
\hline
\end{tabular}


Table 2: Key Information on Top 20 Cities and Towns in terms of the Percentage Change in the Labor Force due to 1989 Repatriates

\begin{tabular}{llcccr}
\hline City/Town & Province & $\begin{array}{c}\text { NUTS-1 } \\
\text { Region }\end{array}$ & $\begin{array}{c}\text { Earlier Repatriates as \% } \\
\text { of Non-Repatriates in } \\
\text { Labor Force in 1985 }\end{array}$ & $\begin{array}{c}\text { \% Change in Labor } \\
\text { Force due to 1989 } \\
\text { Repatriates }\end{array}$ & $\begin{array}{c}1985 \\
\text { Population }\end{array}$ \\
\hline Corlu & Tekirdag & 2 & 9.26 & 10.37 & 59,840 \\
Muratli & Tekirdag & 2 & 13.19 & 10.36 & 10,580 \\
Bursa & Bursa & 4 & 14.78 & 7.39 & 620,040 \\
Cerkezkoy & Tekirdag & 2 & 14.47 & 6.38 & 18,580 \\
Gebze & Kocaeli & 4 & 4.67 & 5.14 & 94,640 \\
Saray & Tekirdag & 2 & 3.54 & 4.94 & 11,520 \\
Orhangazi & Bursa & 4 & 11.53 & 4.73 & 23,240 \\
Yalova & Istanbul & 1 & 3.56 & 4.00 & 54,380 \\
Silivri & Istanbul & 1 & 1.58 & 3.46 & 15,540 \\
Luleburgaz & Kirklareli & 2 & 6.93 & 3.13 & 44,460 \\
Tekirdag & Tekirdag & 2 & 1.75 & 3.07 & 64,100 \\
Inegol & Bursa & 4 & 3.30 & 2.54 & 56,760 \\
Malkara & Tekirdag & 2 & 0.26 & 2.16 & 18,540 \\
Babaeski & Kirklareli & 2 & 5.10 & 2.10 & 20,500 \\
Edirne & Edirne & 2 & 2.21 & 1.94 & 85,940 \\
Catalca & Istanbul & 1 & 1.01 & 1.89 & 11,200 \\
Saruhanli & Manisa & 3 & 9.09 & 1.72 & 12,600 \\
Eskisehir & Eskisehir & 4 & 3.13 & 1.65 & 371,900 \\
Hayrabolu & Tekirdag & 2 & 1.97 & 1.60 & 16,860 \\
Izmir & Izmir & 3 & 1.49 & 1.55 & $1,496,800$ \\
\hline Notes: & & & & & \\
\hline
\end{tabular}

Notes: The cities and towns in this list are restricted to those with a population greater than 10,000 in 1985 . There were 342 such locations in Turkey in 1985. Turkey was divided into 67 administrative provinces in 1985 . These provinces, in turn, form 12 NUTS-1 level statis tical regions. 
Table 3 - Characteristics of Repatriates and Non-Repatriates, Means, Year 1990

\begin{tabular}{lrrrrr}
\hline & \multicolumn{2}{c}{ Non-repatriate } & & \multicolumn{2}{c}{ Repatriate } \\
\cline { 2 - 3 } \cline { 5 - 6 } & Male & Female & & Male & Female \\
\hline Age & 32.6 & 29.7 & 35.3 & 31.8 \\
Education & & & & \\
Illiterate & 4.6 & 8.1 & & 2.2 & 1.4 \\
Less than primary school & 2.1 & 1.7 & & 2.3 & 1.5 \\
Primary school & 54.6 & 29.1 & & 8.5 & 8.7 \\
Junior high school & 12.1 & 9.2 & 32.7 & 40.2 \\
High school & 16.7 & 31.2 & & 47.9 & 40.6 \\
University & 9.9 & 20.7 & & 6.4 & 7.6 \\
Industry & & & & \\
Farming, forestry, fishing & 5.1 & 10.3 & & 1.3 & 1.5 \\
Mining & 0.6 & 0.1 & & 0.4 & 0.0 \\
Manufacturing & 20.4 & 21.5 & & 42.0 & 61.6 \\
Hydro & 0.7 & 0.3 & & 0.1 & 0.1 \\
Construction & 9.4 & 0.5 & 15.1 & 0.6 \\
Wholesale, retail trade, hotels and restaurants & 16.3 & 7.6 & 10.2 & 10.6 \\
Transport, Communication services & 6.5 & 2.4 & 5.8 & 0.5 \\
Financial, insurance & 4.1 & 9.9 & 2.0 & 2.6 \\
Social or private services & 25.9 & 33.4 & 12.2 & 17.1 \\
Others & 11.0 & 13.9 & 11.0 & 5.5 \\
Labor Force Participation Rate & $82.7 \%$ & $15.9 \%$ & $90.7 \%$ & $58.6 \%$ \\
Unemployment Rate & $9.9 \%$ & $12.9 \%$ & $9.8 \%$ & $4.4 \%$ \\
\hline Number of Observations & 500,233 & 443,109 & 2,529 & 2,656 \\
\hline
\end{tabular}

Notes: The sample consists of 16 to 65 year old individuals in the 1990 Census who live in cities and towns with a population above 10,000 in 1985. Except for the labor force participation rate, all variables are calculated for labor force participants. For natives, migration status is determined based on place of residence 5 years ago. Earlier repatriates are included among the "nonrepatriate" group. 
Table 4: The Distribution of Cities and Towns in the Sample in Treatment and Comparison Groups by the Estimated Propensity Score Deciles

\begin{tabular}{|c|c|c|c|c|c|c|c|c|c|c|c|}
\hline \multicolumn{12}{|c|}{ A) Treatment: Actual Increase in the Labor Force due to 1989 Repatriates > 1 percent } \\
\hline & \multicolumn{10}{|c|}{$\begin{array}{l}\text { Estimated Propensity Score Deciles } \\
\end{array}$} & \multirow[b]{2}{*}{ Total } \\
\hline & 1 & 2 & 3 & 4 & 5 & 6 & 7 & 8 & 9 & 10 & \\
\hline Treatment & 0 & 0 & 0 & 0 & 0 & 0 & 1 & 1 & 3 & 26 & 31 \\
\hline Comparison & 34 & 34 & 34 & 35 & 34 & 34 & 34 & 33 & 31 & 8 & 311 \\
\hline Total & 34 & 34 & 34 & 35 & 34 & 34 & 35 & 34 & 34 & 34 & 342 \\
\hline
\end{tabular}

B) Treatment: Actual Increase in the Labor Force due to 1989 Repatriates $>2$ percent

\begin{tabular}{lcccccccccccr}
\hline & \multicolumn{10}{c}{ Estimated Propensity Score Deciles } & \\
\cline { 2 - 11 } & 1 & 2 & 3 & 4 & 5 & 6 & 7 & 8 & 9 & 10 & Total \\
\cline { 2 - 11 } Treatment & 0 & 0 & 0 & 0 & 0 & 0 & 0 & 0 & 0 & 14 & 14 \\
Comparison & 34 & 34 & 34 & 35 & 34 & 34 & 35 & 34 & 34 & 20 & 328 \\
\hline Total & 34 & 34 & 34 & 35 & 34 & 34 & 35 & 34 & 34 & 34 & 342 \\
\hline
\end{tabular}

C) Treatment: Actual Increase in the Labor Force due to 1989 Repatriates $>4$ percent

\begin{tabular}{lccccccccccccr}
\hline & \multicolumn{10}{c}{ Estimated Propensity Score Deciles } & \\
\cline { 2 - 10 } & 1 & 2 & 3 & 4 & 5 & 6 & 7 & 8 & 9 & 10 & Total \\
\cline { 2 - 9 } Treatment & 0 & 0 & 0 & 0 & 0 & 0 & 0 & 0 & 0 & 8 & 8 \\
Comparison & 34 & 34 & 34 & 35 & 34 & 34 & 35 & 34 & 34 & 26 & 334 \\
\hline Total & 34 & 34 & 34 & 35 & 34 & 34 & 35 & 34 & 34 & 34 & 342 \\
\hline
\end{tabular}

Notes: The sample includes 342 cities and towns with a 1985 population that is greater than 10,000 . Propensity score stands for the predicted increase in the labor force due to 1989 repatriates for a location based on its 1985 characteristics. These characteristics include the shares of age groups (16-25, 26-35, 36-45, 46-55, 56-65) by gender, five education groups (less than primary, primary, junior-high, high school, university), and 9 sectors of employment in the labor force, as well as log population, unemployment rate and 67 province dummies. 
Table 5: Effect of the Increase in the Labor Supply in 1989 due to Repatriates on Unemployment Rate of Non-repatriates by Gender

\begin{tabular}{|c|c|c|c|c|c|c|c|c|}
\hline \multicolumn{9}{|c|}{ A) Population $>10,000$} \\
\hline & & \multicolumn{3}{|c|}{ Men } & \multicolumn{3}{|c|}{ Women } & \multirow[b]{2}{*}{ No. obs } \\
\hline Propensity Score & & Coef. & $\mathrm{SE}$ & $\mathrm{R}-\mathrm{Sq}$ & Coef. & SE & $\mathrm{R}-\mathrm{Sq}$ & \\
\hline & OLS & $0.293 * *$ & $(0.119)$ & 0.509 & -0.211 & $(0.351)$ & 0.612 & 342 \\
\hline \multirow[t]{2}{*}{ All } & 2SLS & $0.263 *$ & $(0.135)$ & 0.509 & -0.290 & $(0.303)$ & 0.612 & 342 \\
\hline & OLS & $0.307 * *$ & $(0.135)$ & 0.614 & -0.289 & $(0.382)$ & 0.662 & 274 \\
\hline \multirow[t]{2}{*}{ Top 80 Percentile } & 2SLS & $0.294 *$ & $(0.155)$ & 0.614 & -0.238 & $(0.335)$ & 0.662 & 274 \\
\hline & OLS & $0.363 * *$ & $(0.161)$ & 0.652 & -0.225 & $(0.404)$ & 0.677 & 205 \\
\hline \multirow[t]{2}{*}{ Top 60 Percentile } & 2SLS & $0.364 * *$ & $(0.178)$ & 0.652 & -0.202 & $(0.360)$ & 0.677 & 205 \\
\hline & OLS & $0.357 * *$ & $(0.174)$ & 0.717 & -0.141 & $(0.408)$ & 0.750 & 137 \\
\hline \multirow[t]{2}{*}{ Top 40 Percentile } & 2SLS & $0.397 * *$ & $(0.192)$ & 0.716 & -0.199 & $(0.361)$ & 0.750 & 137 \\
\hline & OLS & $0.364 *$ & $(0.214)$ & 0.665 & -0.032 & $(0.441)$ & 0.746 & 102 \\
\hline Top 30 Percentile & 2SLS & $0.417 *$ & $(0.220)$ & 0.664 & -0.107 & $(0.388)$ & 0.746 & 102 \\
\hline
\end{tabular}

B) $1,000,000>$ Population $>10,000$

\begin{tabular}{|c|c|c|c|c|c|c|c|c|}
\hline \multirow[b]{2}{*}{ Propensity Score } & & \multicolumn{3}{|c|}{ Men } & \multicolumn{3}{|c|}{ Women } & \multirow[b]{2}{*}{ No. obs } \\
\hline & & Coef. & $\mathrm{SE}$ & $\mathrm{R}-\mathrm{Sq}$ & Coef. & SE & $\mathrm{R}-\mathrm{Sq}$ & \\
\hline & OLS & $0.342 * * *$ & $(0.117)$ & 0.506 & -0.308 & $(0.341)$ & 0.624 & 339 \\
\hline \multirow[t]{2}{*}{ All } & 2SLS & $0.282^{* *}$ & $(0.136)$ & 0.506 & -0.339 & $(0.301)$ & 0.624 & 339 \\
\hline & OLS & $0.347 * * *$ & $(0.125)$ & 0.582 & -0.356 & $(0.384)$ & 0.678 & 271 \\
\hline \multirow[t]{2}{*}{ Top 80 Percentile } & 2SLS & $0.322 * *$ & $(0.143)$ & 0.582 & -0.278 & $(0.337)$ & 0.678 & 271 \\
\hline & OLS & $0.444 * * *$ & $(0.162)$ & 0.669 & -0.225 & $(0.388)$ & 0.702 & 204 \\
\hline \multirow[t]{2}{*}{ Top 60 Percentile } & 2SLS & $0.436 * *$ & $(0.184)$ & 0.669 & -0.225 & $(0.352)$ & 0.702 & 204 \\
\hline & OLS & $0.446^{* *}$ & $(0.186)$ & 0.762 & -0.138 & $(0.447)$ & 0.782 & 136 \\
\hline \multirow[t]{2}{*}{ Top 40 Percentile } & 2SLS & $0.436 * *$ & $(0.215)$ & 0.762 & -0.172 & $(0.388)$ & 0.782 & 136 \\
\hline & OLS & $0.458 *$ & $(0.236)$ & 0.739 & -0.076 & $(0.451)$ & 0.782 & 101 \\
\hline Top 30 Percentile & 2SLS & $0.502 *$ & $(0.268)$ & 0.738 & -0.139 & $(0.386)$ & 0.782 & 101 \\
\hline \multicolumn{9}{|c|}{ C) $1,000,000>$ Population $>25,000$} \\
\hline & & & Men & & & Women & & \\
\hline \multirow[t]{2}{*}{ Propensity Score } & & Coef. & SE & $\mathrm{R}-\mathrm{Sq}$ & Coef. & $\mathrm{SE}$ & $\mathrm{R}-\mathrm{Sq}$ & No. obs \\
\hline & OLS & $0.465 * * *$ & $(0.169)$ & 0.760 & 0.005 & $(0.702)$ & 0.768 & 150 \\
\hline \multirow[t]{2}{*}{ All } & 2SLS & $0.484 * *$ & $(0.186)$ & 0.760 & 0.151 & $(0.562)$ & 0.767 & 150 \\
\hline & OLS & $0.568 * * *$ & $(0.192)$ & 0.817 & 0.028 & $(0.777)$ & 0.783 & 135 \\
\hline \multirow[t]{2}{*}{ Top 90 Percentile } & 2SLS & $0.575^{* *}$ & $(0.229)$ & 0.817 & 0.200 & $(0.643)$ & 0.783 & 135 \\
\hline & OLS & $0.619 * * *$ & $(0.224)$ & 0.853 & 0.126 & $(0.844)$ & 0.796 & 120 \\
\hline \multirow[t]{2}{*}{ Top 80 Percentile } & 2SLS & $0.624 * *$ & $(0.259)$ & 0.853 & 0.280 & $(0.730)$ & 0.796 & 120 \\
\hline & OLS & $0.668^{* *}$ & $(0.293)$ & 0.859 & 0.184 & $(0.994)$ & 0.818 & 105 \\
\hline \multirow[t]{2}{*}{ Top 70 Percentile } & 2SLS & $0.640 *$ & $(0.332)$ & 0.859 & 0.336 & $(0.869)$ & 0.817 & 105 \\
\hline & OLS & $0.756^{* *}$ & $(0.285)$ & 0.878 & 0.503 & $(0.812)$ & 0.860 & 90 \\
\hline Top 60 Percentile & 2SLS & $0.744 * *$ & $(0.338)$ & 0.878 & 0.804 & $(0.671)$ & 0.859 & 90 \\
\hline
\end{tabular}

Notes: The control variables include the shares for age-groups (16-25, 26-35, 36-45, 46-55, 56-65), for five education groups (less than primary, primary, junior high, high school, university graduates) and for 9 sectors of employment, as well as province dummies. Small sample correction (degrees of adjustment of $\mathrm{N} /(\mathrm{N}-\mathrm{k})$ to the variance-covariance matrix) is done. Propensity score denotes the predicted fraction of 1989 repatriates in the labor force of a location based on its 1985 characteristics. *** significant at 1 percent level, ** at 5 percent level, * at 10 percent level. 
Table 6: Comparison of Treatment and Comparison Group Characteristics by Propensity Score - Cities and Towns with Population $>10000$

\begin{tabular}{|c|c|c|c|c|c|c|}
\hline & \multirow[t]{2}{*}{$\begin{array}{c}\text { Treatment } \\
\text { Group } \\
\end{array}$} & \multicolumn{5}{|c|}{$\begin{array}{c}\text { Comparison } \\
\text { Group }\end{array}$} \\
\hline & & All & $\begin{array}{c}\text { Top } 60 \\
\text { Percentile }\end{array}$ & $\begin{array}{c}\text { Top } 40 \\
\text { Percentile }\end{array}$ & $\begin{array}{c}\text { Top } 30 \\
\text { Percentile }\end{array}$ & $\begin{array}{c}\text { Top 20 } \\
\text { Percentile }\end{array}$ \\
\hline & $(1)$ & $(2)$ & (3) & (4) & (5) & $(6)$ \\
\hline Mean Unemployment Rate & $8.2 \%$ & $13.7 \% * * *$ & $13.0 \% * * *$ & $11.6 \% * * *$ & $11.0 \% * *$ & $9.6 \%$ \\
\hline Mean Population & 74,411 & 79,480 & 107,061 & 144,064 & 180,903 & 197,646 \\
\hline Shares of Sectors of Employment & & & & & & \\
\hline Farming, forestry, fishing & $6.2 \%$ & $17.4 \% * * *$ & $15.3 \% * * *$ & $13.7 \% * * *$ & $13.1 \% * * *$ & $12.4 \% * *$ \\
\hline Mining & $0.9 \%$ & $1.3 \%$ & $1.2 \%$ & $1.2 \%$ & $1.0 \%$ & $0.8 \%$ \\
\hline Manufacturing & $27.3 \%$ & $15.1 \% * * *$ & $18.2 \% * *$ & $19.5 \% *$ & $21.5 \%$ & $22.7 \%$ \\
\hline Hydroelectric & $0.1 \%$ & $0.3 \% *$ & $0.3 \% *$ & $0.3 \%$ & $0.2 \%$ & $0.2 \%$ \\
\hline Construction & $7.6 \%$ & $7.2 \%$ & $7.3 \%$ & $7.2 \%$ & $7.0 \%$ & $6.6 \%$ \\
\hline Trade, hotels and restaurants & $14.0 \%$ & $13.8 \%$ & $13.9 \%$ & $14.0 \%$ & $13.8 \%$ & $13.0 \%$ \\
\hline Transportation, communications & $5.0 \%$ & $6.9 \% * * *$ & $6.5 \% * *$ & $6.4 \% * *$ & $6.0 \%$ & $5.7 \%$ \\
\hline Financial Services & $3.4 \%$ & $3.2 \%$ & $3.4 \%$ & $3.6 \%$ & $3.7 \%$ & $3.6 \%$ \\
\hline Social or Private Services & $34.8 \%$ & $33.9 \%$ & $33.0 \%$ & $33.1 \%$ & $32.8 \%$ & $34.1 \%$ \\
\hline Shares of Education Groups & & & & & & \\
\hline Illiterate & $4.9 \%$ & $9.2 \% * * *$ & $7.6 \% * * *$ & $7.2 \% * * *$ & $6.9 \% * * *$ & $6.3 \% *$ \\
\hline Less Than Primary School & $3.3 \%$ & $4.4 \% * * *$ & $4.1 \% * * *$ & $3.8 \% *$ & $3.8 \% *$ & $3.7 \%$ \\
\hline Primary School Graduate & $57.6 \%$ & $51.7 \% * * *$ & $52.9 \% * * *$ & $53.8 \% * * *$ & $54.7 \% * *$ & $53.9 \% * *$ \\
\hline Secondary School Graduate & $11.6 \%$ & $11.0 \%$ & $11.2 \%$ & $11.0 \%$ & $10.7 \%$ & $11.0 \%$ \\
\hline High School Graduate & $16.0 \%$ & $17.0 \%$ & $17.3 \%$ & $17.1 \%$ & $16.8 \%$ & $17.6 \%$ \\
\hline University Graduate & $6.6 \%$ & $6.7 \%$ & $6.9 \%$ & $7.0 \%$ & $7.2 \%$ & $7.5 \%$ \\
\hline Shares of Age Groups & & & & & & \\
\hline $16-25$ & $39.6 \%$ & $34.9 \% *$ & $34.4 \% *$ & $34.5 \% *$ & $34.6 \% *$ & $35.4 \%$ \\
\hline $26-35$ & $31.2 \%$ & $31.2 \%$ & $31.9 \%$ & $31.8 \%$ & $31.6 \%$ & $31.4 \%$ \\
\hline $36-45$ & $16.0 \%$ & $18.7 \% * * *$ & $18.7 \% * * *$ & $18.5 \% * * *$ & $18.8 \% * * *$ & $18.7 \% * * *$ \\
\hline $46-55$ & $9.5 \%$ & $11.0 \% *$ & $11.0 \% *$ & $11.1 \% * *$ & $11.0 \% *$ & $10.7 \%$ \\
\hline $56-65$ & $3.7 \%$ & $4.2 \%$ & $4.0 \%$ & $4.1 \%$ & $4.0 \%$ & $3.8 \%$ \\
\hline Share Female & $10.9 \%$ & $11.4 \%$ & $12.2 \%$ & $12.3 \%$ & $12.8 \% *$ & $12.8 \%$ \\
\hline
\end{tabular}


Table 7: Effect of the Increase in the Labor Supply in 1989 due to Repatriates on Unemployment Rate of Male Non-repatriates by Education

\begin{tabular}{|c|c|c|c|c|c|c|c|c|}
\hline \multirow{2}{*}{ Propensity Score } & & \multicolumn{3}{|c|}{ A) Less Than Primary School } & \multicolumn{3}{|c|}{ B) Primary School } & \multirow[b]{2}{*}{ No. obs } \\
\hline & & Coef. & SE & $\mathrm{R}-\mathrm{Sq}$ & Coef. & SE & $\mathrm{R}-\mathrm{Sq}$ & \\
\hline & OLS & 0.313 & $(0.422)$ & 0.284 & $0.301 * *$ & $(0.123)$ & 0.499 & 342 \\
\hline \multirow[t]{2}{*}{ All } & 2SLS & 0.316 & $(0.412)$ & 0.284 & $0.260 *$ & $(0.147)$ & 0.499 & 342 \\
\hline & OLS & 0.153 & $(0.447)$ & 0.375 & $0.316 * *$ & $(0.134)$ & 0.578 & 274 \\
\hline \multirow[t]{2}{*}{ Top 80 Percentile } & 2SLS & 0.202 & $(0.411)$ & 0.375 & $0.303 *$ & $(0.157)$ & 0.578 & 274 \\
\hline & OLS & 0.061 & $(0.509)$ & 0.479 & $0.317 * *$ & $(0.142)$ & 0.621 & 205 \\
\hline \multirow[t]{2}{*}{ Top 60 Percentile } & 2SLS & 0.140 & $(0.485)$ & 0.479 & $0.331 * *$ & $(0.160)$ & 0.621 & 205 \\
\hline & OLS & -0.019 & $(0.500)$ & 0.524 & $0.290^{*}$ & $(0.156)$ & 0.621 & 137 \\
\hline \multirow[t]{2}{*}{ Top 40 Percentile } & 2SLS & 0.228 & $(0.530)$ & 0.523 & $0.343 *$ & $(0.179)$ & 0.620 & 137 \\
\hline & OLS & -0.320 & $(0.556)$ & 0.556 & 0.278 & $(0.167)$ & 0.594 & 102 \\
\hline \multirow[t]{2}{*}{ Top 30 Percentile } & 2SLS & -0.049 & $(0.536)$ & 0.554 & $0.319 *$ & $(0.190)$ & 0.594 & 102 \\
\hline & & \multicolumn{3}{|c|}{ C) Junior-High or High School } & \multicolumn{3}{|c|}{ D) University } & \\
\hline \multirow[t]{2}{*}{ Propensity Score } & & Coef. & SE & $\mathrm{R}-\mathrm{Sq}$ & Coef. & SE & $\mathrm{R}-\mathrm{Sq}$ & No. obs \\
\hline & OLS & $0.458 * * *$ & $(0.136)$ & 0.429 & -0.105 & $(0.190)$ & 0.256 & 342 \\
\hline \multirow[t]{2}{*}{ All } & 2SLS & $0.384 * *$ & $(0.156)$ & 0.429 & -0.157 & $(0.232)$ & 0.256 & 342 \\
\hline & OLS & $0.492 * * *$ & $(0.158)$ & 0.497 & -0.162 & $(0.200)$ & 0.290 & 274 \\
\hline \multirow[t]{2}{*}{ Top 80 Percentile } & 2SLS & $0.404 * *$ & $(0.181)$ & 0.497 & -0.191 & $(0.236)$ & 0.290 & 274 \\
\hline & OLS & $0.554 * * *$ & $(0.185)$ & 0.552 & -0.177 & $(0.199)$ & 0.415 & 205 \\
\hline \multirow[t]{2}{*}{ Top 60 Percentile } & 2SLS & $0.573 * * *$ & $(0.201)$ & 0.552 & -0.123 & $(0.273)$ & 0.415 & 205 \\
\hline & OLS & $0.615^{* *}$ & $(0.244)$ & 0.650 & -0.075 & $(0.177)$ & 0.586 & 137 \\
\hline \multirow[t]{2}{*}{ Top 40 Percentile } & 2SLS & $0.586 * *$ & $(0.249)$ & 0.649 & -0.043 & $(0.249)$ & 0.586 & 137 \\
\hline & OLS & $0.637 * *$ & $(0.272)$ & 0.675 & -0.091 & $(0.204)$ & 0.647 & 102 \\
\hline Top 30 Percentile & 2SLS & $0.596 * *$ & $(0.293)$ & 0.675 & -0.135 & $(0.238)$ & 0.646 & 102 \\
\hline
\end{tabular}

Notes: The sample is restricted to locations with a population greater than 10,000. The dependent variable in each panel -- unemployment rate of non-repatriates -- is by education level whereas the key variable of interest -- the increase in the labor supply due to the 1989 repatriates -- is at the aggregate level. The control variables include the shares for age-groups $(16-25,26-35,36-45$, 46-55, 56-65), for five education groups (less than primary, primary, junior high, high school, university graduates) and for 9 sectors of employment, as well as province dummies. Small sample correction (degrees of adjustment of $\mathrm{N} /(\mathrm{N}-\mathrm{k})$ to the variance-covariance matrix) is done. Propensity score denotes the predicted fraction of 1989 repatriates in the labor force of a location based on its 1985 characteristics. $* * *$ significant at 1 percent level, ** at 5 percent level, $*$ at 10 percent level. 
Table 8: Effect of the Increase in the Labor Supply in 1989 due to Repatriates on Unemployment Rate of Male Non-repatriates by Age and Education

\begin{tabular}{|c|c|c|c|c|c|c|c|c|}
\hline \multicolumn{9}{|l|}{ A) Primary School } \\
\hline & & \multicolumn{3}{|c|}{ A1) Ages: 16-30 } & \multicolumn{3}{|c|}{ A2) Ages 31-65 } & \multirow[b]{2}{*}{ No. obs } \\
\hline \multicolumn{2}{|l|}{ Propensity Score } & Coef. & $\mathrm{SE}$ & $\mathrm{R}-\mathrm{Sq}$ & Coef. & $\mathrm{SE}$ & $\mathrm{R}-\mathrm{Sq}$ & \\
\hline & OLS & 0.333 & $(0.226)$ & 0.433 & 0.226 & $(0.150)$ & 0.357 & 342 \\
\hline \multirow[t]{2}{*}{ All } & 2SLS & $0.502 * *$ & $(0.215)$ & 0.432 & 0.017 & $(0.176)$ & 0.354 & 342 \\
\hline & OLS & 0.331 & $(0.235)$ & 0.505 & 0.236 & $(0.155)$ & 0.440 & 274 \\
\hline \multirow[t]{2}{*}{ Top 80 Percentile } & 2SLS & $0.535 * *$ & $(0.223)$ & 0.503 & 0.045 & $(0.183)$ & 0.436 & 274 \\
\hline & OLS & 0.392 & $(0.243)$ & 0.559 & 0.222 & $(0.160)$ & 0.494 & 205 \\
\hline \multirow[t]{2}{*}{ Top 60 Percentile } & 2SLS & $0.603 * * *$ & $(0.228)$ & 0.557 & 0.081 & $(0.189)$ & 0.491 & 205 \\
\hline & OLS & 0.378 & $(0.278)$ & 0.552 & 0.195 & $(0.179)$ & 0.539 & 137 \\
\hline \multirow[t]{2}{*}{ Top 40 Percentile } & 2SLS & $0.657 * *$ & $(0.286)$ & 0.546 & 0.032 & $(0.196)$ & 0.533 & 137 \\
\hline & OLS & 0.346 & $(0.290)$ & 0.562 & 0.161 & $(0.180)$ & 0.557 & 102 \\
\hline Top 30 Percentile & 2SLS & $0.597 * *$ & $(0.247)$ & 0.555 & -0.006 & $(0.196)$ & 0.546 & 102 \\
\hline
\end{tabular}

B) Junior High or High School

\begin{tabular}{|c|c|c|c|c|c|c|c|c|}
\hline \multirow[b]{2}{*}{ Propensity Score } & & \multicolumn{3}{|c|}{ B1) Ages: 16-30 } & \multicolumn{3}{|c|}{ B2) Ages 31-65 } & \multirow[b]{2}{*}{ No. obs } \\
\hline & & Coef. & SE & $\mathrm{R}-\mathrm{Sq}$ & Coef. & SE & $\mathrm{R}-\mathrm{Sq}$ & \\
\hline & OLS & $0.703 * * *$ & $(0.252)$ & 0.377 & -0.006 & $(0.151)$ & 0.261 & 342 \\
\hline \multirow[t]{2}{*}{ All } & 2SLS & $0.718 * * *$ & $(0.269)$ & 0.377 & -0.131 & $(0.156)$ & 0.260 & 342 \\
\hline & OLS & $0.720 * *$ & $(0.275)$ & 0.421 & -0.021 & $(0.153)$ & 0.292 & 274 \\
\hline \multirow[t]{2}{*}{ Top 80 Percentile } & 2SLS & $0.750 * *$ & $(0.294)$ & 0.421 & -0.141 & $(0.158)$ & 0.290 & 274 \\
\hline & OLS & $0.699 * *$ & $(0.298)$ & 0.498 & 0.048 & $(0.164)$ & 0.344 & 205 \\
\hline \multirow[t]{2}{*}{ Top 60 Percentile } & 2SLS & $0.777 * *$ & $(0.313)$ & 0.498 & -0.099 & $(0.173)$ & 0.341 & 205 \\
\hline & OLS & $0.804 * *$ & $(0.332)$ & 0.618 & 0.095 & $(0.166)$ & 0.485 & 137 \\
\hline \multirow[t]{2}{*}{ Top 40 Percentile } & 2SLS & $0.901 * *$ & $(0.345)$ & 0.617 & -0.078 & $(0.176)$ & 0.479 & 137 \\
\hline & OLS & $0.872 * *$ & $(0.397)$ & 0.629 & 0.099 & $(0.178)$ & 0.585 & 102 \\
\hline Top 30 Percentile & 2SLS & $0.958 * *$ & $(0.438)$ & 0.629 & -0.034 & $(0.185)$ & 0.580 & 102 \\
\hline
\end{tabular}

Notes: The sample is restricted to locations with a population greater than 10,000. The dependent variable in each panel -- unemployment rate of non-repatriates -- is by age and education level whereas the key variable of interest -- the increase in the labor supply due to the 1989 repatriates -- is at the aggregate level. The control variables include the shares for age-groups (16-25, 26-35, 36-45, 46-55, 56-65), for five education groups (less than primary, primary, junior high, high school, university graduates) and for 9 sectors of employment, as well as province dummies. Small sample correction (degrees of adjustment of $\mathrm{N} /(\mathrm{N}-\mathrm{k})$ to the variance-covariance matrix) is done. Propensity score denotes the predicted fraction of 1989 repatriates in the labor force of a location based on its 1985 characteristics. *** significant at 1 percent level, $* *$ at 5 percent level, $*$ at 10 percent level. 
Table 9: Effect of the Increase in the Labor Supply in 1989 due to Repatriates on Employment Rate of Non-repatriates by Gender

\begin{tabular}{|c|c|c|c|c|c|c|c|c|}
\hline \multicolumn{9}{|c|}{ A) Population $>10,000$} \\
\hline \multirow[b]{2}{*}{ Propensity Score } & & \multicolumn{3}{|c|}{ Men } & \multicolumn{3}{|c|}{ Women } & \multirow[b]{2}{*}{ No. obs } \\
\hline & & Coef. & SE & $\mathrm{R}-\mathrm{Sq}$ & Coef. & SE & $\mathrm{R}-\mathrm{Sq}$ & \\
\hline & OLS & -0.215 & $(0.212)$ & 0.550 & -0.090 & $(0.106)$ & 0.381 & 342 \\
\hline \multirow[t]{2}{*}{ All } & 2SLS & -0.262 & $(0.203)$ & 0.550 & -0.203 & $(0.159)$ & 0.380 & 342 \\
\hline & OLS & -0.235 & $(0.217)$ & 0.643 & -0.093 & $(0.119)$ & 0.455 & 274 \\
\hline \multirow[t]{2}{*}{ Top 80 Percentile } & 2SLS & -0.278 & $(0.209)$ & 0.643 & -0.216 & $(0.171)$ & 0.454 & 274 \\
\hline & OLS & -0.261 & $(0.245)$ & 0.693 & -0.097 & $(0.133)$ & 0.485 & 205 \\
\hline \multirow[t]{2}{*}{ Top 60 Percentile } & 2SLS & -0.312 & $(0.231)$ & 0.693 & -0.243 & $(0.196)$ & 0.483 & 205 \\
\hline & OLS & -0.314 & $(0.264)$ & 0.758 & -0.160 & $(0.165)$ & 0.568 & 137 \\
\hline \multirow[t]{2}{*}{ Top 40 Percentile } & 2SLS & -0.393 & $(0.259)$ & 0.758 & -0.369 & $(0.235)$ & 0.562 & 137 \\
\hline & OLS & -0.240 & $(0.300)$ & 0.727 & -0.111 & $(0.197)$ & 0.633 & 102 \\
\hline Top 30 Percentile & 2SLS & -0.293 & $(0.307)$ & 0.726 & -0.298 & $(0.292)$ & 0.627 & 102 \\
\hline \multicolumn{9}{|c|}{ B) $1,000,000>$ Population $>10,000$} \\
\hline & & & Men & & & Women & & \\
\hline \multirow[t]{2}{*}{ Propensity Score } & & Coef. & SE & $\mathrm{R}-\mathrm{Sq}$ & Coef. & SE & $\mathrm{R}-\mathrm{Sq}$ & No. obs \\
\hline & OLS & -0.289 & $(0.197)$ & 0.538 & -0.101 & $(0.108)$ & 0.375 & 339 \\
\hline \multirow[t]{2}{*}{ All } & 2SLS & -0.316 & $(0.197)$ & 0.538 & -0.208 & $(0.164)$ & 0.375 & 339 \\
\hline & OLS & -0.302 & $(0.198)$ & 0.601 & -0.098 & $(0.124)$ & 0.434 & 271 \\
\hline \multirow[t]{2}{*}{ Top 80 Percentile } & 2SLS & $-0.349 *$ & $(0.200)$ & 0.601 & -0.221 & $(0.177)$ & 0.433 & 271 \\
\hline & OLS & $-0.381 *$ & $(0.221)$ & 0.689 & -0.097 & $(0.146)$ & 0.471 & 204 \\
\hline \multirow[t]{2}{*}{ Top 60 Percentile } & 2SLS & $-0.411 *$ & $(0.226)$ & 0.689 & -0.239 & $(0.212)$ & 0.469 & 204 \\
\hline & OLS & $-0.451 *$ & $(0.263)$ & 0.764 & -0.271 & $(0.181)$ & 0.597 & 136 \\
\hline \multirow[t]{2}{*}{ Top 40 Percentile } & 2SLS & $-0.500 *$ & $(0.274)$ & 0.764 & $-0.455^{*}$ & $(0.243)$ & 0.593 & 136 \\
\hline & OLS & -0.398 & $(0.304)$ & 0.777 & -0.124 & $(0.221)$ & 0.568 & 101 \\
\hline Top 30 Percentile & 2SLS & -0.482 & $(0.329)$ & 0.776 & -0.305 & $(0.316)$ & 0.562 & 101 \\
\hline \multicolumn{9}{|c|}{ C) $1,000,000>$ Population $>25,000$} \\
\hline & & & Men & & & Women & & \\
\hline \multirow[t]{2}{*}{ Propensity Score } & & Coef. & SE & $\mathrm{R}-\mathrm{Sq}$ & Coef. & SE & $\mathrm{R}-\mathrm{Sq}$ & No. obs \\
\hline & OLS & $-0.368 *$ & $(0.220)$ & 0.786 & -0.151 & $(0.167)$ & 0.568 & 150 \\
\hline \multirow[t]{2}{*}{ All } & 2SLS & -0.362 & $(0.222)$ & 0.786 & -0.260 & $(0.173)$ & 0.567 & 150 \\
\hline & OLS & $-0.481 * * *$ & $(0.177)$ & 0.850 & -0.204 & $(0.198)$ & 0.566 & 135 \\
\hline \multirow[t]{2}{*}{ Top 90 Percentile } & 2SLS & $-0.473 * *$ & $(0.177)$ & 0.850 & -0.313 & $(0.223)$ & 0.565 & 135 \\
\hline & OLS & $-0.515^{* *}$ & $(0.230)$ & 0.884 & -0.188 & $(0.276)$ & 0.605 & 120 \\
\hline \multirow[t]{2}{*}{ Top 80 Percentile } & 2SLS & $-0.533 * *$ & $(0.244)$ & 0.884 & -0.308 & $(0.349)$ & 0.603 & 120 \\
\hline & OLS & $-0.397 *$ & $(0.227)$ & 0.903 & -0.290 & $(0.434)$ & 0.616 & 105 \\
\hline \multirow[t]{2}{*}{ Top 70 Percentile } & 2SLS & -0.394 & $(0.239)$ & 0.903 & -0.484 & $(0.515)$ & 0.612 & 105 \\
\hline & OLS & $-0.607 *$ & $(0.327)$ & 0.908 & -0.376 & $(0.506)$ & 0.630 & 90 \\
\hline Top 60 Percentile & 2SLS & $-0.629 *$ & $(0.353)$ & 0.908 & -0.613 & $(0.590)$ & 0.624 & 90 \\
\hline
\end{tabular}

Notes: The control variables include the shares for age-groups (16-25, 26-35, 36-45, 46-55, 56-65), for five education groups (less than primary, primary, junior high, high school, university graduates) and for 9 sectors of employment, as well as province dummies. Small sample correction (degrees of adjustment of N/(N-k) to the variance-covariance matrix) is done. Propensity score denotes the predicted fraction of 1989 repatriates in the labor force of a location based on its 1985 characteristics. *** significant at 1 percent level, ** at 5 percent level, * at 10 percent level. 
Table 10: Effect of the Increase in the Labor Supply in 1989 due to Repatriates on Labor Force Participation of Non-repatriates by Gender

\begin{tabular}{|c|c|c|c|c|c|c|c|c|}
\hline \multicolumn{9}{|c|}{ A) Population $>10,000$} \\
\hline \multirow[b]{2}{*}{ Propensity Score } & & \multicolumn{3}{|c|}{ Men } & \multicolumn{3}{|c|}{ Women } & \multirow[b]{2}{*}{ No. obs } \\
\hline & & Coef. & SE & $\mathrm{R}-\mathrm{Sq}$ & Coef. & SE & $\mathrm{R}-\mathrm{Sq}$ & \\
\hline & OLS & 0.043 & $(0.158)$ & 0.511 & -0.097 & $(0.117)$ & 0.391 & 342 \\
\hline \multirow[t]{2}{*}{ All } & 2SLS & -0.019 & $(0.152)$ & 0.511 & -0.222 & $(0.179)$ & 0.391 & 342 \\
\hline & OLS & 0.023 & $(0.161)$ & 0.585 & -0.115 & $(0.126)$ & 0.472 & 274 \\
\hline \multirow[t]{2}{*}{ Top 80 Percentile } & 2SLS & -0.034 & $(0.155)$ & 0.585 & -0.238 & $(0.184)$ & 0.471 & 274 \\
\hline & OLS & 0.054 & $(0.183)$ & 0.693 & -0.125 & $(0.148)$ & 0.518 & 205 \\
\hline \multirow[t]{2}{*}{ Top 60 Percentile } & 2SLS & 0.000 & $(0.168)$ & 0.692 & -0.281 & $(0.205)$ & 0.516 & 205 \\
\hline & OLS & 0.042 & $(0.203)$ & 0.734 & -0.183 & $(0.191)$ & 0.568 & 137 \\
\hline \multirow[t]{2}{*}{ Top 40 Percentile } & 2SLS & -0.005 & $(0.186)$ & 0.733 & -0.407 & $(0.259)$ & 0.562 & 137 \\
\hline & OLS & 0.099 & $(0.206)$ & 0.715 & -0.088 & $(0.221)$ & 0.635 & 102 \\
\hline Top 30 Percentile & 2SLS & 0.080 & $(0.192)$ & 0.715 & -0.288 & $(0.308)$ & 0.629 & 102 \\
\hline \multicolumn{9}{|c|}{ B) $1,000,000>$ Population $>10,000$} \\
\hline & & & Men & & & Women & & \\
\hline \multirow[t]{2}{*}{ Propensity Score } & & Coef. & SE & $\mathrm{R}-\mathrm{Sq}$ & Coef. & SE & $\mathrm{R}-\mathrm{Sq}$ & No. obs \\
\hline & OLS & 0.018 & $(0.151)$ & 0.503 & -0.116 & $(0.121)$ & 0.388 & 339 \\
\hline \multirow[t]{2}{*}{ All } & 2SLS & -0.052 & $(0.148)$ & 0.503 & -0.231 & $(0.186)$ & 0.387 & 339 \\
\hline & OLS & 0.006 & $(0.153)$ & 0.569 & -0.124 & $(0.130)$ & 0.457 & 271 \\
\hline \multirow[t]{2}{*}{ Top 80 Percentile } & 2SLS & -0.068 & $(0.151)$ & 0.569 & -0.249 & $(0.191)$ & 0.456 & 271 \\
\hline & OLS & 0.024 & $(0.170)$ & 0.688 & -0.132 & $(0.163)$ & 0.489 & 204 \\
\hline \multirow[t]{2}{*}{ Top 60 Percentile } & 2SLS & -0.028 & $(0.159)$ & 0.687 & -0.288 & $(0.223)$ & 0.486 & 204 \\
\hline & OLS & -0.001 & $(0.207)$ & 0.736 & -0.303 & $(0.203)$ & 0.595 & 136 \\
\hline \multirow[t]{2}{*}{ Top 40 Percentile } & 2SLS & -0.078 & $(0.188)$ & 0.735 & $-0.494 *$ & $(0.268)$ & 0.591 & 136 \\
\hline & OLS & 0.046 & $(0.202)$ & 0.749 & -0.136 & $(0.242)$ & 0.574 & 101 \\
\hline Top 30 Percentile & 2SLS & -0.032 & $(0.194)$ & 0.748 & -0.328 & $(0.330)$ & 0.567 & 101 \\
\hline \multicolumn{9}{|c|}{ C) $1,000,000>$ Population $>25,000$} \\
\hline & & & Men & & & Women & & \\
\hline \multirow[t]{2}{*}{ Propensity Score } & & Coef. & SE & $\mathrm{R}-\mathrm{Sq}$ & Coef. & SE & $\mathrm{R}-\mathrm{Sq}$ & No. obs \\
\hline & OLS & -0.004 & $(0.200)$ & 0.700 & -0.158 & $(0.154)$ & 0.635 & 150 \\
\hline \multirow[t]{2}{*}{ All } & 2SLS & -0.015 & $(0.168)$ & 0.700 & -0.265 & $(0.172)$ & 0.634 & 150 \\
\hline & OLS & 0.012 & $(0.192)$ & 0.734 & -0.230 & $(0.192)$ & 0.635 & 135 \\
\hline \multirow[t]{2}{*}{ Top 90 Percentile } & 2SLS & -0.008 & $(0.162)$ & 0.734 & -0.335 & $(0.226)$ & 0.634 & 135 \\
\hline & OLS & -0.018 & $(0.221)$ & 0.805 & -0.252 & $(0.268)$ & 0.678 & 120 \\
\hline \multirow[t]{2}{*}{ Top 80 Percentile } & 2SLS & -0.095 & $(0.180)$ & 0.804 & -0.363 & $(0.342)$ & 0.677 & 120 \\
\hline & OLS & 0.127 & $(0.261)$ & 0.854 & -0.308 & $(0.408)$ & 0.680 & 105 \\
\hline \multirow[t]{2}{*}{ Top 70 Percentile } & 2SLS & 0.046 & $(0.243)$ & 0.853 & -0.496 & $(0.492)$ & 0.677 & 105 \\
\hline & OLS & 0.036 & $(0.340)$ & 0.873 & -0.364 & $(0.487)$ & 0.685 & 90 \\
\hline Top 60 Percentile & 2SLS & -0.114 & $(0.305)$ & 0.871 & -0.578 & $(0.581)$ & 0.680 & 90 \\
\hline
\end{tabular}

Notes: The control variables include the shares for age-groups (16-25, 26-35, 36-45, 46-55, 56-65), for five education groups (less than primary, primary, junior high, high school, university graduates) and for 9 sectors of employment, as well as province dummies. Small sample correction (degrees of adjustment of N/(N-k) to the variance-covariance matrix) is done. Propensity score denotes the predicted fraction of 1989 repatriates in the labor force of a location based on its 1985 characteristics. *** significant at 1 percent level, ** at 5 percent level, * at 10 percent level. 
Figure 1 - Immigrant flows from Bulgaria 1934-51

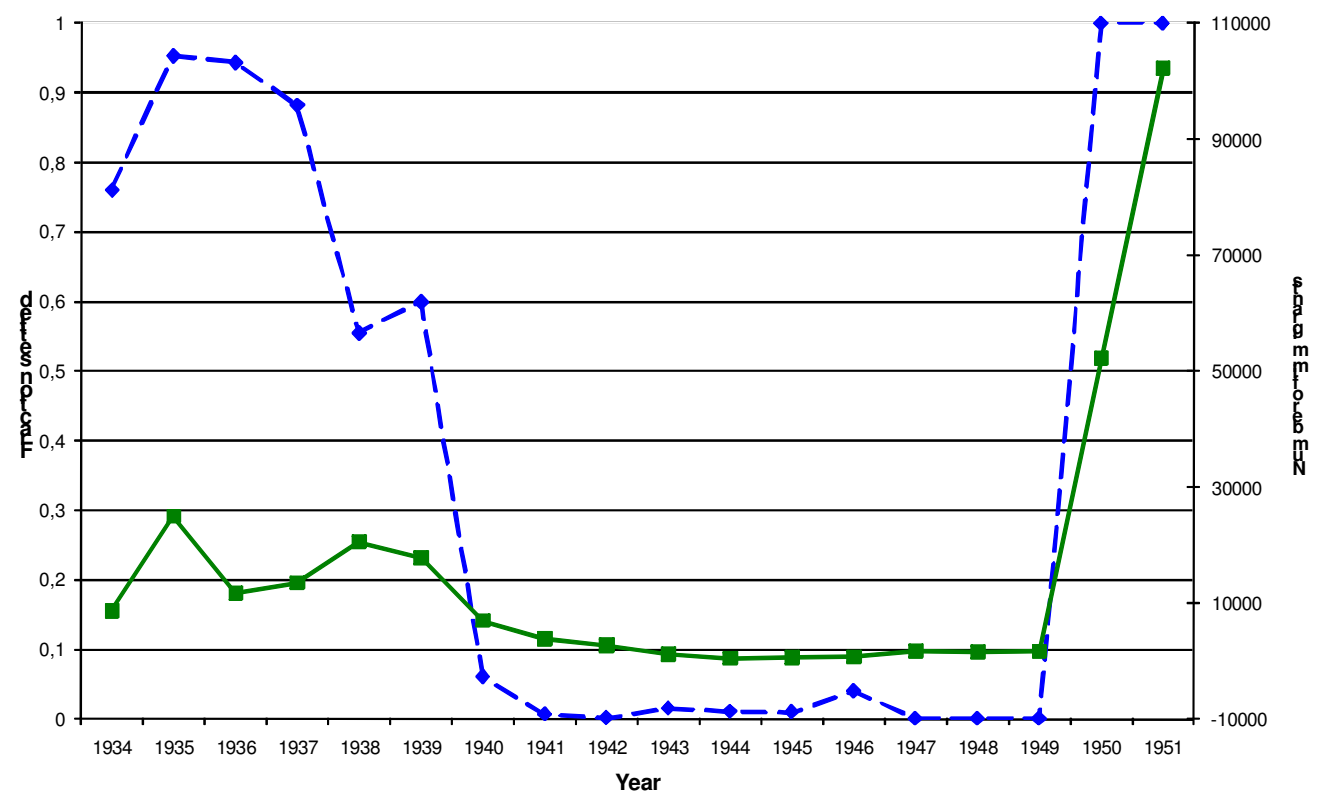

Notes: 1. Dashed line refers to "Fraction settled", solid line refers to "Number of immigrants".

2. The info about the number of migrants that were settled by the state is available for the 1934-60 period. Most of the 1968 cohort that came as part of family reunification agreement were not settled by the state although there are no exact numbers. This information is also not known for the 1989 cohort. After 1951 with the exception of the 1968 and 1989 flows migration from Bulgaria has almost ceased. There may have been very few migrants that fled the country illegally while no exact numbers are available.

Source: Geray, C. (1962), Türkiye'den ve Türkiye'ye Göçler, Ankara. 
Figure 2 - Housing Construction for Immigrants, 1934-1960

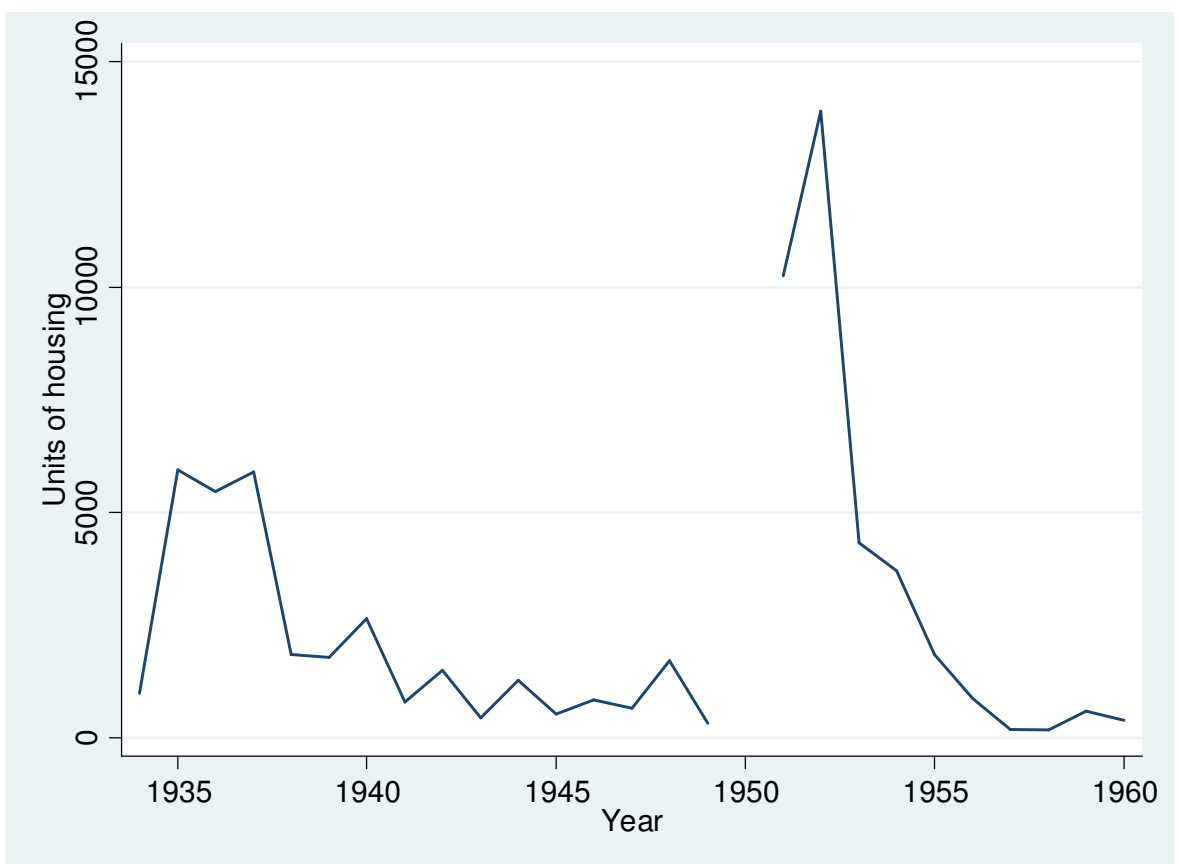

Notes: The number of housing units for 1950 is unknown.

Source: Geray, C. (1962), Türkiye'den ve Türkiye'ye Göçler, Ankara. 
Figure 3 - Provincial distribution of settled 1950-51 cohort at the time of settlement and the provincial distribution of repatriates in 1985 Census

A - All provinces

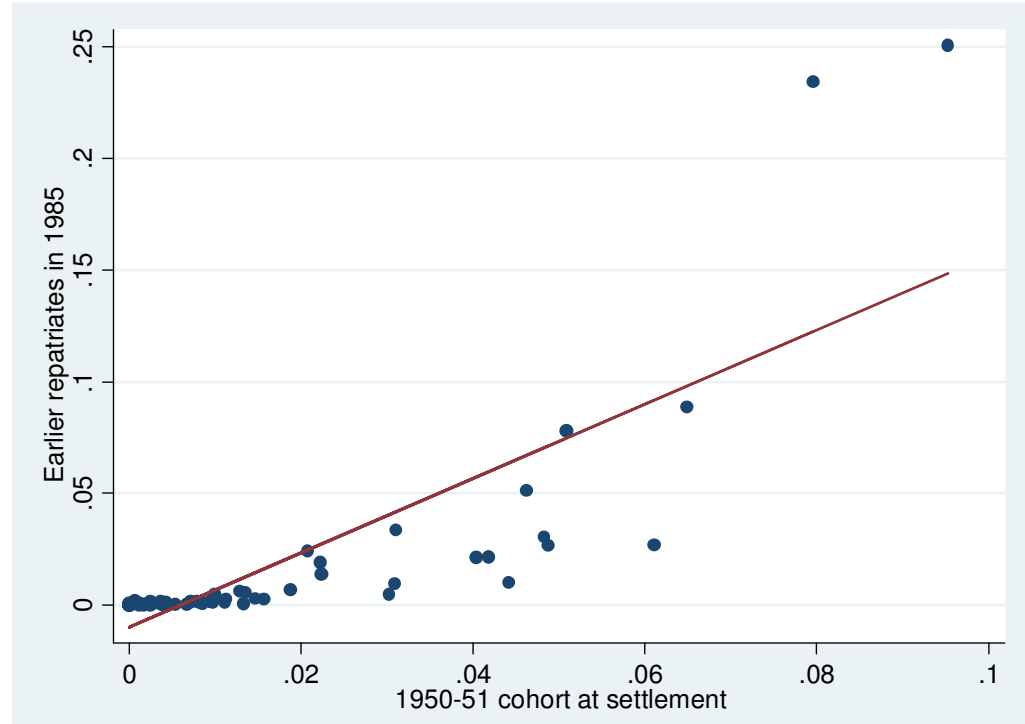

B - Provinces with provincial share of repatriates in $1985>0.01$

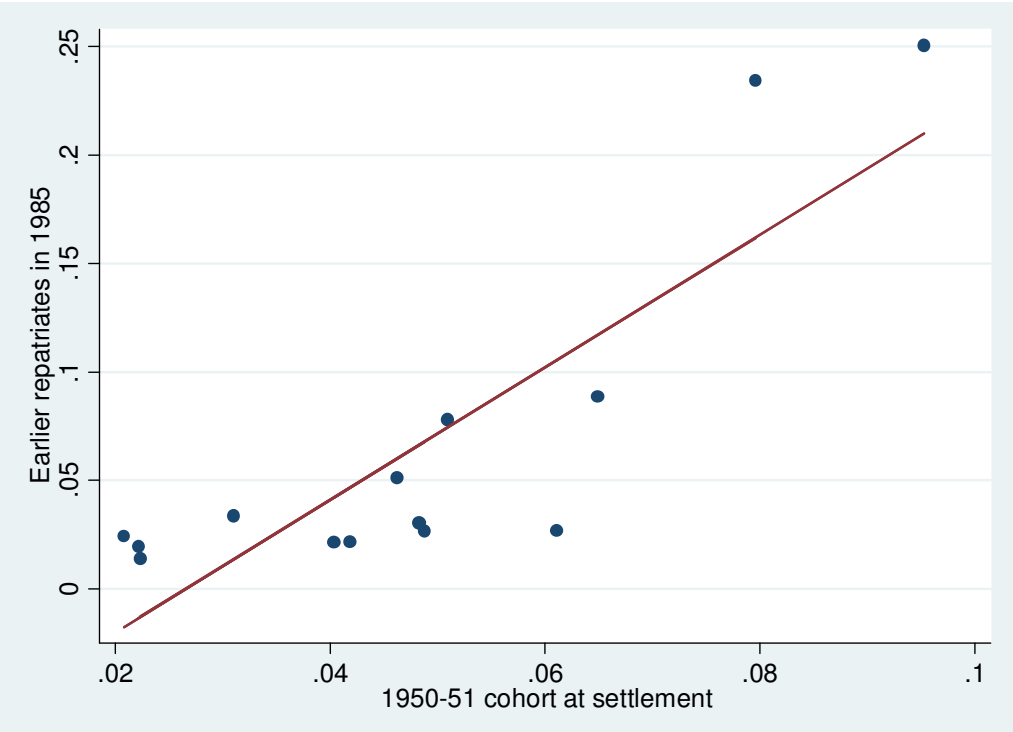

Notes: Horizontal axis (x) refers to provincial share of settled earlier repatriates that arrived during 1950-51 period. The vertical axis (y) refers to provincial share of earlier repatriates in 1985 (thus excludes repatriates who arrived in 1989). The fitted line refers to the regression of $\mathrm{y}$ on $\mathrm{x}$. 
Figure 4 - Map of Turkey

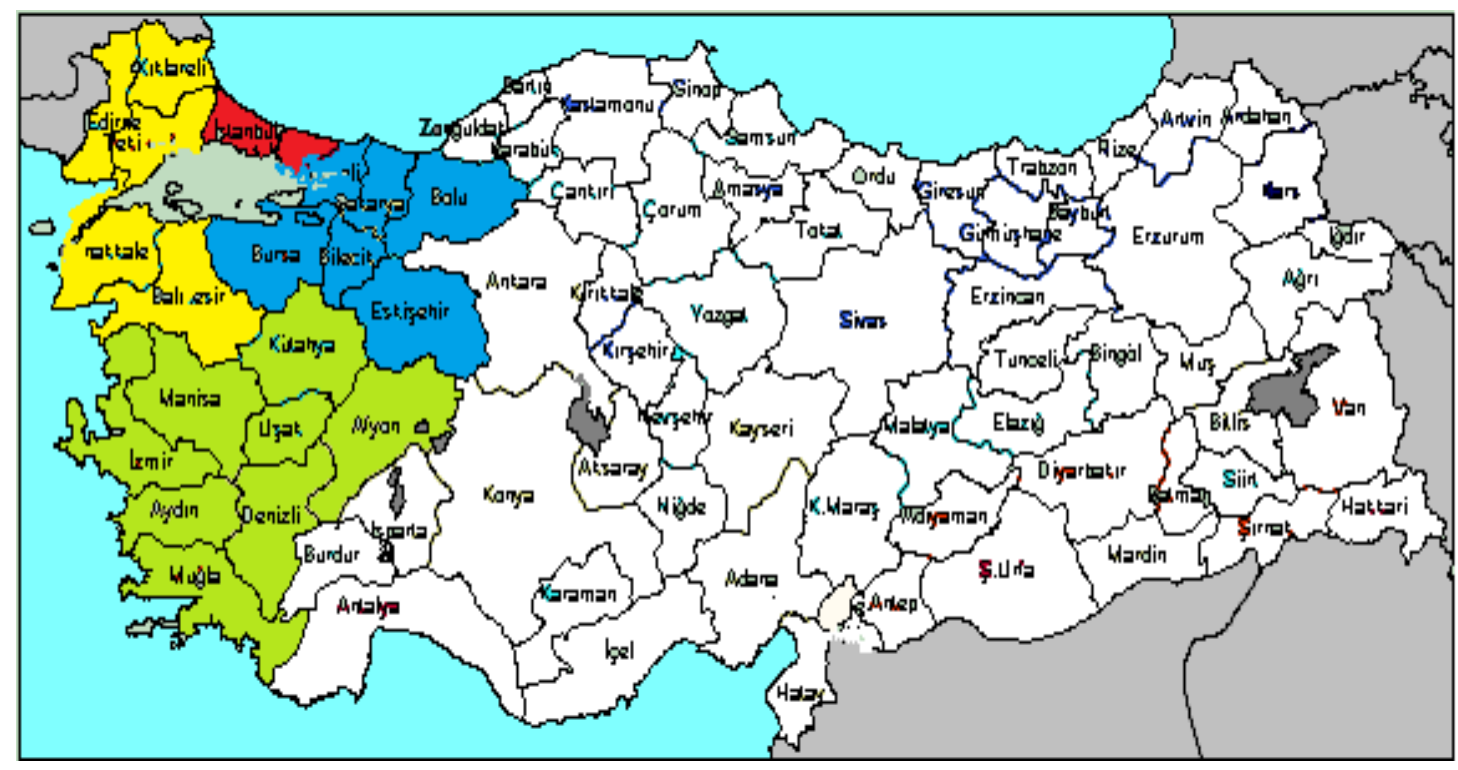

Notes: Turkey is divided into 12 NUTS1 regions. NUTS1-1 region (Istanbul) is in red, NUTS1-2 region (West Marmara) is in yellow, NUTS1-3 region (Aegean) is in green, and NUTS1-4 region (East Marmara) is in blue. 


\section{APPENDIX}

Table A1: Geographical Distribution of Cities and Towns in Different Samples Defined by Estimated Propensity Score

\begin{tabular}{lrrrrrrrrrrrrr}
\hline NUTS-1 Region & 1 & 2 & 3 & 4 & 5 & 6 & 7 & 8 & 9 & 10 & 11 & 12 & Total \\
\hline All & 3 & 31 & 53 & 29 & 24 & 38 & 29 & 35 & 28 & 16 & 23 & 33 & 342 \\
Top 30 Percentile & 3 & 27 & 21 & 21 & 6 & 5 & 5 & 6 & 2 & 1 & 1 & 4 & 102 \\
\hline
\end{tabular}

Notes: The sample includes 342 cities and towns with a 1985 population that is greater than 10,000. Propensity score stands for the predicted increase in the labor force due to 1989 repatriates for a location based on its 1985 characteristics. These characteristics include the shares of age groups (16-25, 26-35, 36-45, 46-55, 56-65) by gender, five education groups (less than primary, primary, junior-high, high school, university), and 9 sectors of employment in the labor force, as well as log population, unemployment rate and 67 province dummies. 
Table A2: Instrument Check

\begin{tabular}{|c|c|c|}
\hline & \multicolumn{2}{|c|}{ Dependent Variable } \\
\hline & $\begin{array}{c}\text { Increase in Labor } \\
\text { Supply due to } 1989 \\
\text { Repatriates }\end{array}$ & $\begin{array}{c}\text { Share of Other In-Migrants } \\
\text { after } 1985 \text { in the } 1990 \\
\text { Labor Force }\end{array}$ \\
\hline Repatriate/Non-Repatriate in 1985 & $\begin{array}{c}0.495^{* * *} \\
(0.048)\end{array}$ & $\begin{array}{c}0.180 \\
(0.179)\end{array}$ \\
\hline Unemployment Rate, 1985 & $\begin{array}{c}0.005 \\
(0.007) \\
\end{array}$ & $\begin{array}{c}-0.125^{* *} \\
(0.059) \\
\end{array}$ \\
\hline R-squared & 0.948 & 0.782 \\
\hline No. obs & 342 & 342 \\
\hline
\end{tabular}

Notes: The sample includes cities and towns with a population higher than 10,000 in 1985. Other in-migrants include all migrants coming from abroad (excluding the 1989 repatriates from Bulgaria) and other provinces, as well as those coming from the rural areas of the same province that the city or town belongs to. The control variables include the shares for age-groups (16-25, 26-35, 36-45, 46-55, 56-65) by gender, for five education groups, and for 9 sectors of employment in the labor force, as well as log population and province dummies. Small sample correction (degrees of adjustment of $\mathrm{N} /(\mathrm{N}-\mathrm{k})$ to the variance-covariance matrix) is done. $* * *$ significant at 1 percent level, ** at 5 percent level, * at 10 percent level. 
Table A3: First-Stage Results for Unemployment Rate Equation for Men

\begin{tabular}{llccc}
\hline A) Population $>10,000$ & & & & \\
\hline \hline Propensity Score & Coef. & SE & Partial F-stat. & No. obs \\
\hline All & $0.531^{* * *}$ & $(0.047)$ & 126.5 & 342 \\
Top 80 Percentile & $0.534^{* * *}$ & $(0.049)$ & 120.9 & 274 \\
Top 60 Percentile & $0.538^{* * *}$ & $(0.051)$ & 111.9 & 205 \\
Top 40 Percentile & $0.538^{* * *}$ & $(0.055)$ & 97.0 & 137 \\
Top 30 Percentile & $0.540^{* * *}$ & $(0.061)$ & 79.5 & 102 \\
\hline
\end{tabular}

B) $1,000,000>$ Population $>10,000$

\begin{tabular}{llccc}
\hline \hline Propensity Score & Coef. & SE & F-stat. & No. obs \\
\hline All & $0.521^{* * *}$ & $(0.046)$ & 127.9 & 339 \\
Top 80 Percentile & $0.523^{* * *}$ & $(0.047)$ & 123.3 & 271 \\
Top 60 Percentile & $0.525^{* * *}$ & $(0.050)$ & 111.2 & 204 \\
Top 40 Percentile & $0.524 * * *$ & $(0.055)$ & 91.6 & 136 \\
Top 30 Percentile & $0.532^{* * *}$ & $(0.056)$ & 90.9 & 101 \\
\hline
\end{tabular}

C) $1,000,000>$ Population $>25,000$

\begin{tabular}{llccc}
\hline \hline Propensity Score & Coef. & SE & F-stat. & No. obs \\
\hline All & $0.558^{* * * *}$ & $(0.062)$ & 81.0 & 150 \\
Top 90 Percentile & $0.559^{* * *}$ & $(0.063)$ & 78.2 & 135 \\
Top 80 Percentile & $0.561 * * *$ & $(0.068)$ & 69.1 & 120 \\
Top 70 Percentile & $0.550^{* * *}$ & $(0.062)$ & 79.4 & 105 \\
Top 60 Percentile & $0.561 * * *$ & $(0.065)$ & 75.5 & 90 \\
\hline
\end{tabular}

Notes: The control variables include the shares for age-groups (16-25, 26-35, 36-45, 46-55, 56-65), for five education groups (less than primary, primary, junior high, high school, university graduates), for 9 sectors of employment, as well as province dummies. Small sample correction (degrees of adjustment of $\mathrm{N} /(\mathrm{N}-\mathrm{k})$ to the variance-covariance matrix) is done. Propensity score denotes the predicted fraction of 1989 repatriates in the labor force of a location based on its 1985 characteristics. $* * *$ significant at 1 percent level, $* *$ at 5 percent level, $*$ at 10 percent level. 
Table A4: Effect of the Increase in the Labor Supply in 1989 due to Repatriates on the Share of Other Male In-Migrants in the Labor Force

\begin{tabular}{lllllc}
\hline A) Population $>10,000$ & & & & & \\
\hline \hline Propensity Score & & Coef. & SE & R-Sq & No. obs \\
\hline \multirow{3}{*}{ All } & OLS & 0.037 & $(0.162)$ & 0.367 & 342 \\
& 2SLS & 0.029 & $(0.174)$ & 0.367 & 342 \\
\hline \multirow{2}{*}{ Top 80 Percentile } & OLS & 0.008 & $(0.170)$ & 0.410 & 274 \\
& 2SLS & 0.057 & $(0.189)$ & 0.410 & 274 \\
Top 60 Percentile & OLS & -0.003 & $(0.198)$ & 0.498 & 205 \\
& 2SLS & 0.083 & $(0.221)$ & 0.498 & 205 \\
Top 40 Percentile & OLS & -0.048 & $(0.250)$ & 0.569 & 137 \\
& 2SLS & 0.025 & $(0.251)$ & 0.569 & 137 \\
Top 30 Percentile & OLS & -0.006 & $(0.306)$ & 0.543 & 102 \\
\hline
\end{tabular}

B) $1,000,000>$ Population $>10,000$

\begin{tabular}{|c|c|c|c|c|c|}
\hline Propensity Score & & Coef. & SE & $\mathrm{R}-\mathrm{Sq}$ & No. obs \\
\hline & OLS & 0.107 & $(0.158)$ & 0.365 & 339 \\
\hline \multirow[t]{2}{*}{ All } & 2SLS & 0.063 & $(0.177)$ & 0.365 & 339 \\
\hline & OLS & 0.102 & (0.169) & 0.415 & 271 \\
\hline \multirow[t]{2}{*}{ Top 80 Percentile } & 2SLS & 0.113 & $(0.191)$ & 0.415 & 271 \\
\hline & OLS & 0.079 & $(0.196)$ & 0.481 & 204 \\
\hline \multirow[t]{2}{*}{ Top 60 Percentile } & 2SLS & 0.121 & $(0.224)$ & 0.481 & 204 \\
\hline & OLS & 0.095 & $(0.235)$ & 0.563 & 136 \\
\hline \multirow[t]{2}{*}{ Top 40 Percentile } & 2SLS & 0.147 & $(0.261)$ & 0.563 & 136 \\
\hline & OLS & 0.041 & $(0.326)$ & 0.627 & 101 \\
\hline Top 30 Percentile & 2SLS & 0.070 & $(0.371)$ & 0.627 & 101 \\
\hline \multicolumn{6}{|c|}{ C) $1,000,000>$ Population $>25,000$} \\
\hline \multirow[t]{2}{*}{ Propensity Score } & & Coef. & $\mathrm{SE}$ & $\mathrm{R}-\mathrm{Sq}$ & No. obs \\
\hline & OLS & 0.155 & $(0.321)$ & 0.661 & 150 \\
\hline \multirow[t]{2}{*}{ All } & 2SLS & 0.004 & $(0.334)$ & 0.660 & 150 \\
\hline & OLS & 0.167 & $(0.376)$ & 0.684 & 135 \\
\hline \multirow[t]{2}{*}{ Top 80 Percentile } & 2SLS & -0.024 & $(0.406)$ & 0.682 & 135 \\
\hline & OLS & 0.168 & $(0.428)$ & 0.738 & 120 \\
\hline \multirow[t]{2}{*}{ Top 60 Percentile } & 2SLS & -0.005 & $(0.424)$ & 0.736 & 120 \\
\hline & OLS & 0.271 & $(0.444)$ & 0.787 & 105 \\
\hline \multirow[t]{2}{*}{ Top 40 Percentile } & 2SLS & 0.067 & $(0.380)$ & 0.784 & 105 \\
\hline & OLS & 0.071 & $(0.563)$ & 0.818 & 90 \\
\hline Top 30 Percentile & 2SLS & -0.242 & $(0.553)$ & 0.812 & 90 \\
\hline
\end{tabular}

Notes: The control variables include the shares for age-groups (16-25, 26-35, 36-45, 46-55, 56-65), for five education groups (less than primary, primary, junior high, high school, university graduates), for 9 sectors of employment, as well as province dummies. Small sample correction (degrees of adjustment of N/(N-k) to the variance-covariance matrix) is done. Propensity score denotes the predicted fraction of 1989 repatriates in the labor force of a location based on its 1985 characteristics. *** significant at 1 percent level, $* *$ at 5 percent level, $*$ at 10 percent level. 
Table A5: Effect of the Increase in the Labor Supply in 1989 due to Repatriates on Unemployment and Employment/Population of Male Non-repatriates - Non-repatriates Excludes Repatriates Before 1985

\begin{tabular}{|c|c|c|c|c|c|c|c|c|}
\hline \multicolumn{9}{|c|}{ A) Population $>10,000$} \\
\hline \multirow[b]{2}{*}{ Propensity Score } & & \multicolumn{3}{|c|}{ Unemployment Rate } & \multicolumn{3}{|c|}{ Employment / Population } & \multirow[b]{2}{*}{ No. obs } \\
\hline & & Coef. & SE & $\mathrm{R}-\mathrm{Sq}$ & Coef. & SE & $\mathrm{R}-\mathrm{Sq}$ & \\
\hline \multirow[b]{2}{*}{ All } & OLS & $0.283 * *$ & $(0.127)$ & 0.508 & -0.238 & $(0.217)$ & 0.549 & 342 \\
\hline & 2SLS & $0.284 * *$ & $(0.141)$ & 0.508 & -0.291 & $(0.204)$ & 0.549 & 342 \\
\hline \multirow{3}{*}{ Top 80 Percentile } & OLS & $0.300 * *$ & $(0.142)$ & 0.613 & -0.246 & $(0.222)$ & 0.643 & 274 \\
\hline & 2SLS & $0.317 * *$ & $(0.158)$ & 0.613 & -0.289 & $(0.210)$ & 0.643 & 274 \\
\hline & OLS & $0.361 * *$ & $(0.169)$ & 0.652 & -0.268 & $(0.251)$ & 0.697 & 205 \\
\hline \multirow[t]{2}{*}{ Top 60 Percentile } & 2SLS & $0.398 * *$ & $(0.182)$ & 0.652 & -0.329 & $(0.232)$ & 0.696 & 205 \\
\hline & OLS & $0.373 *$ & $(0.188)$ & 0.711 & -0.322 & $(0.272)$ & 0.763 & 137 \\
\hline \multirow[t]{2}{*}{ Top 40 Percentile } & 2SLS & $0.444 * *$ & $(0.201)$ & 0.710 & -0.406 & $(0.265)$ & 0.762 & 137 \\
\hline & OLS & 0.372 & $(0.231)$ & 0.654 & -0.246 & $(0.310)$ & 0.730 & 102 \\
\hline Top 30 Percentile & 2SLS & $0.460 *$ & $(0.244)$ & 0.652 & -0.310 & $(0.315)$ & 0.729 & 102 \\
\hline
\end{tabular}

B) $1,000,000>$ Population $>10,000$

\begin{tabular}{|c|c|c|c|c|c|c|c|c|}
\hline \multirow[b]{2}{*}{ Propensity Score } & & \multicolumn{3}{|c|}{ "Unemployment Rate } & \multicolumn{3}{|c|}{ Employment / Population } & \multirow[b]{2}{*}{ No. obs } \\
\hline & & Coef. & SE & $\mathrm{R}-\mathrm{Sq}$ & Coef. & SE & $\mathrm{R}-\mathrm{Sq}$ & \\
\hline \multirow[b]{2}{*}{ All } & OLS & $0.335^{* * *}$ & $(0.125)$ & 0.504 & -0.311 & $(0.204)$ & 0.535 & 339 \\
\hline & 2SLS & $0.305^{* *}$ & $(0.141)$ & 0.504 & $-0.342 *$ & $(0.201)$ & 0.535 & 339 \\
\hline \multirow{3}{*}{ Top 80 Percentile } & OLS & $0.333 * *$ & $(0.133)$ & 0.579 & -0.310 & $(0.207)$ & 0.599 & 271 \\
\hline & 2SLS & $0.335^{* *}$ & $(0.148)$ & 0.579 & $-0.358^{*}$ & $(0.204)$ & 0.599 & 271 \\
\hline & OLS & $0.441 * * *$ & $(0.167)$ & 0.667 & -0.381 & $(0.231)$ & 0.688 & 204 \\
\hline \multirow[t]{2}{*}{ Top 60 Percentile } & 2SLS & $0.462 * *$ & $(0.185)$ & 0.667 & $-0.411^{*}$ & $(0.229)$ & 0.688 & 204 \\
\hline & OLS & $0.471 * *$ & $(0.194)$ & 0.756 & -0.457 & $(0.277)$ & 0.764 & 136 \\
\hline \multirow[t]{2}{*}{ Top 40 Percentile } & 2SLS & $0.484 * *$ & $(0.223)$ & 0.756 & $-0.500 *$ & $(0.285)$ & 0.764 & 136 \\
\hline & OLS & $0.466^{*}$ & $(0.245)$ & 0.726 & -0.393 & $(0.317)$ & 0.779 & 101 \\
\hline Top 30 Percentile & 2SLS & $0.529 *$ & $(0.272)$ & 0.725 & -0.481 & $(0.336)$ & 0.778 & 101 \\
\hline
\end{tabular}

C) $1,000,000>$ Population $>25,000$

\begin{tabular}{|c|c|c|c|c|c|c|c|c|}
\hline \multirow[b]{2}{*}{ Propensity Score } & & \multicolumn{3}{|c|}{ Unemployment Rate } & \multicolumn{3}{|c|}{ Employment / Population } & \multirow[b]{2}{*}{ No. obs } \\
\hline & & Coef. & SE & $\mathrm{R}-\mathrm{Sq}$ & Coef. & SE & $\mathrm{R}-\mathrm{Sq}$ & \\
\hline & OLS & $0.445 * *$ & $(0.177)$ & 0.759 & -0.341 & $(0.225)$ & 0.789 & 150 \\
\hline \multirow[t]{2}{*}{ All } & 2SLS & $0.483 * *$ & $(0.185)$ & 0.759 & -0.334 & $(0.215)$ & 0.789 & 150 \\
\hline & OLS & $0.584 * * *$ & $(0.196)$ & 0.814 & $-0.461 * *$ & $(0.190)$ & 0.849 & 135 \\
\hline \multirow[t]{2}{*}{ Top 90 Percentile } & 2SLS & $0.614 * * *$ & $(0.222)$ & 0.814 & $-0.455^{* *}$ & $(0.180)$ & 0.849 & 135 \\
\hline & OLS & $0.635^{* *}$ & $(0.234)$ & 0.849 & $-0.478^{*}$ & $(0.246)$ & 0.882 & 120 \\
\hline \multirow[t]{2}{*}{ Top 80 Percentile } & 2SLS & $0.662 * *$ & $(0.258)$ & 0.849 & $-0.492 *$ & $(0.253)$ & 0.882 & 120 \\
\hline & OLS & $0.733 * *$ & $(0.306)$ & 0.858 & -0.337 & $(0.278)$ & 0.898 & 105 \\
\hline \multirow[t]{2}{*}{ Top 70 Percentile } & 2SLS & $0.728 * *$ & $(0.344)$ & 0.858 & -0.318 & $(0.284)$ & 0.898 & 105 \\
\hline & OLS & $0.801 * *$ & $(0.291)$ & 0.876 & -0.581 & $(0.391)$ & 0.906 & 105 \\
\hline Top 60 Percentile & 2SLS & $0.812 * *$ & $(0.340)$ & 0.876 & -0.603 & $(0.430)$ & 0.906 & 105 \\
\hline
\end{tabular}

Notes: The control variables include the shares for age-groups (16-25, 26-35, 36-45, 46-55, 56-65), for five education groups (less than primary, primary, junior high, high school, university graduates), for 9 sectors of employment, as well as province dummies. Small sample correction (degrees of adjustment of N/(N-k) to the variance-covariance matrix) is done. Propensity score denotes the predicted fraction of 1989 repatriates in the labor force of a location based on its 1985 characteristics. *** significant at 1 percent level, ** at 5 percent level, * at 10 percent level. 
Table A6: Effect of the Increase in the Male Labor Supply in 1989 due to Repatriates on Unemployment and Employment/Population of Male Non-repatriates

\begin{tabular}{|c|c|c|c|c|c|c|c|c|}
\hline \multicolumn{9}{|c|}{ A) Population > 10,000 } \\
\hline \multirow[b]{2}{*}{ Propensity Score } & & \multicolumn{3}{|c|}{ I Unemployment Rate } & \multicolumn{3}{|c|}{ Employment / Population } & \multirow[b]{2}{*}{ No. obs } \\
\hline & & Coef. & SE & R-Sq & Coef. & SE & R-Sq & \\
\hline & OLS & $0.367 * *$ & $\begin{array}{l}(0.169) \\
\end{array}$ & 0.509 & -0.248 & $(0.292)$ & 0.550 & 342 \\
\hline \multirow[t]{2}{*}{ All } & 2SLS & 0.324 & $(0.196)$ & 0.509 & -0.320 & $(0.293)$ & 0.550 & 342 \\
\hline & OLS & $0.374 * *$ & $(0.189)$ & 0.600 & -0.273 & $(0.291)$ & 0.626 & 274 \\
\hline \multirow[t]{2}{*}{ Top 80 Percentile } & 2SLS & $0.408^{*}$ & $(0.210)$ & 0.600 & -0.364 & $(0.289)$ & 0.626 & 274 \\
\hline & OLS & $0.403 * *$ & $(0.204)$ & 0.666 & -0.317 & $(0.319)$ & 0.702 & 205 \\
\hline \multirow[t]{2}{*}{ Top 60 Percentile } & 2SLS & $0.508 * *$ & $(0.228)$ & 0.666 & -0.476 & $(0.316)$ & 0.701 & 205 \\
\hline & OLS & $0.442 *$ & $(0.244)$ & 0.720 & -0.328 & $(0.377)$ & 0.713 & 137 \\
\hline Top 40 Percentile & 2SLS & $0.555^{* *}$ & $(0.271)$ & 0.719 & -0.505 & $(0.376)$ & 0.711 & 137 \\
\hline
\end{tabular}

B) $1,000,000>$ Population $>10,000$

\begin{tabular}{|c|c|c|c|c|c|c|c|c|}
\hline \multirow[b]{2}{*}{ Propensity Score } & & \multicolumn{3}{|c|}{ Unemployment Rate } & \multicolumn{3}{|c|}{ Employment / Population } & \multirow[b]{2}{*}{ No. obs } \\
\hline & & Coef. & SE & $\mathrm{R}-\mathrm{Sq}$ & Coef. & SE & $\mathrm{R}-\mathrm{Sq}$ & \\
\hline & OLS & $0.428 * *$ & $(0.167)$ & 0.505 & -0.337 & $(0.272)$ & 0.537 & 339 \\
\hline \multirow[t]{2}{*}{ All } & 2SLS & $0.354 *$ & $(0.197)$ & 0.505 & -0.403 & $(0.283)$ & 0.537 & 339 \\
\hline & $\overline{\mathrm{OLS}}$ & $0.466^{* *}$ & $(0.184)$ & 0.605 & -0.407 & $(0.265)$ & 0.620 & 272 \\
\hline \multirow[t]{2}{*}{ Top 80 Percentile } & 2SLS & $0.438 * *$ & $(0.210)$ & 0.605 & -0.453 & $(0.285)$ & 0.620 & 272 \\
\hline & $\overline{\mathrm{OLS}}$ & $0.491 * *$ & $(0.201)$ & 0.659 & $-0.470 *$ & $(0.284)$ & 0.689 & 203 \\
\hline \multirow[t]{2}{*}{ Top 60 Percentile } & 2SLS & $0.523 * *$ & $(0.235)$ & 0.659 & $-0.561 *$ & $(0.306)$ & 0.689 & 203 \\
\hline & OLS & $0.554 * *$ & $(0.249)$ & 0.752 & -0.477 & $(0.345)$ & 0.753 & 135 \\
\hline Top 40 Percentile & 2SLS & $0.636^{* *}$ & (0.299) & 0.751 & -0.630 & (0.399) & 0.751 & 135 \\
\hline
\end{tabular}

C) $1,000,000>$ Population $>25,000$

\begin{tabular}{|c|c|c|c|c|c|c|c|c|}
\hline \multirow[b]{2}{*}{ Propensity Score } & & \multicolumn{3}{|c|}{ Unemployment Rate } & \multicolumn{3}{|c|}{ Employment / Population } & \multirow[b]{2}{*}{ No. obs } \\
\hline & & Coef. & SE & $\mathrm{R}-\mathrm{Sq}$ & Coef. & SE & $\mathrm{R}-\mathrm{Sq}$ & \\
\hline \multirow{3}{*}{ All } & OLS & $0.611^{* * * *}$ & $(0.225)$ & 0.759 & -0.481 & $(0.296)$ & 0.786 & 150 \\
\hline & 2SLS & $0.664 * *$ & $(0.260)$ & 0.759 & -0.486 & $(0.308)$ & 0.786 & 150 \\
\hline & OLS & $0.723 * * *$ & $(0.235)$ & 0.791 & $-0.560 * *$ & $(0.234)$ & 0.849 & 135 \\
\hline \multirow[t]{2}{*}{ Top 90 Percentile } & 2SLS & $0.772 * * *$ & $(0.275)$ & 0.791 & $-0.590 * *$ & $(0.228)$ & 0.849 & 135 \\
\hline & OLS & $0.810^{* * * *}$ & $(0.279)$ & 0.838 & $-0.691 * *$ & $(0.279)$ & 0.881 & 120 \\
\hline \multirow[t]{2}{*}{ Top 80 Percentile } & 2SLS & $0.826 * *$ & $(0.339)$ & 0.838 & $-0.707 * *$ & $(0.291)$ & 0.881 & 120 \\
\hline & OLS & 0.893 ** & $(0.367)$ & 0.846 & $-0.680 *$ & $(0.348)$ & 0.897 & 105 \\
\hline Top 70 Percentile & 2SLS & $0.904 *$ & $(0.448)$ & 0.846 & $-0.679 *$ & $(0.393)$ & 0.897 & 105 \\
\hline
\end{tabular}

Notes: The control variables include the shares for age-groups (16-25, 26-35, 36-45, 46-55, 56-65), for five education groups (less than primary, primary, junior high, high school, university graduates), for 9 sectors of employment, as well as province dummies. Small sample correction (degrees of adjustment of $\mathrm{N} /(\mathrm{N}-\mathrm{k})$ to the variance-covariance matrix) is done. Propensity score denotes the predicted fraction of 1989 repatriates in the labor force of a location based on its 1985 characteristics. *** significant at 1 percent level, ** at 5 percent level, * at 10 percent level. 
Table A7: Attenuation Bias (\%)

\begin{tabular}{lcclcc}
\hline & Panel A & Panel B & & Panel C \\
\cline { 2 - 3 } All & 10.5 & 9.9 & & All & 7.6 \\
Top 80 & 9.1 & 9.0 & & Top 90 & 7.6 \\
Top 60 & 7.7 & 8.0 & & Top 80 & 7.3 \\
Top 40 & 6.3 & 6.8 & & Top 70 & 8.3 \\
Top 30 & 5.5 & 6.7 & & Top 60 & 8.4 \\
\hline
\end{tabular}

